\title{
Leh Asıllı Stanislaw Chlebowski'nin Osmanlı Saray Ressamı Olarak İstihdamı ve Ayrılışı
}

\section{Hiring of The Polish Stanislaw Chlebowski as a Court Painter and Resignation}

\author{
Fatma Ürekli* 무
}

"Prof. Dr., Mimar Sinan Güzel Sanatlar Üniversitesi, Fen-Edebiyat Fakültesi, Tarih Bölümü, İstanbul, Türkiye

ORCID: F.Ü. 0000-0003-3247-2339

Sorumlu yazar/Corresponding author: Fatma Ürekli,

Mimar Sinan Güzel Sanatlar Üniversitesi,

Fen-Edebiyat Fakültesi, Tarih Bölümü, Istanbul, Türkiye

E-posta/E-mail: furekli@gmail.com

Başvuru/Submitted: 22.06 .2020

Revizyon Talebi/Revision Requested:

30.06.2020

Son Revizyon/Last Revision Received:

09.07.2020

Kabul/Accepted: 09.07 .2020

\section{Atıf/Citation:}

Urekli, Fatma. "Leh Asıllı Stanislaw Chlebowski'nin Osmanlı Saray Ressamı Olarak İstihdamı ve Ayrılışı." Tarih Dergisi - Turkish Journal of History, 71 (2020): 281-316

https://doi.org/10.26650/TurkJHist.2020.016

\section{ÖZ}

Osmanlı sarayı, devletin idare merkezi olmanın yanı sıra tarih boyunca kültür ve sanat hayatının gelişmesi için önemli rol üstlenmiştir. Farklı alanlarda faaliyet gösteren sanatkârların saray muhitince himâye edilmesi ve çeşitli vesilelerle teşvik edilmesi geleneği, 19. yüzyılda genişleyerek devam etmiştir. Bu yüzyılda itibar gören sanat dallarından birisi resim sanatıdır. Birçok Avrupalı ressamın, Osmanlı sarayında görev almak konusunda istekli ve eserlerini padişaha takdim etme gayreti içinde olduklarını belirtmek gerekir. Bu şekilde hareket eden ressamlardan biri, Leh asıllı Rus vatandaşı Stanislaw Chlebowski'dir. Sultan Abdülaziz tarafından 1870'te "Mâbeyn-i Hümâyûn Ressâmı" tayin edilen Chlebowski, birikimlerini Osmanlı dünyasına taşıma fırsatı bulmuştur. Padişahın talepleri istikâmetinde klasik dönem Osmanlı muharebeleri ve zaferleri yanında, başkent İstanbul'un farklı hatıralarını yansıtan tarihi görsel eserler hazırlamıştır. Hizmeti süresince padişahın takdir ve taltifine mazhar olan ve eserleri ile uluslararası üne ulaşan Chlebowski, bir müddet çalıştıktan sonra sağlık sorunlarını sebep göstererek saray ressamlığından ayrılmıştır.

Anahtar sözcükler: Osmanlı Sarayı, İstanbul, Sultan Abdülaziz, Ressam, Stanislaw Chlebowski, Rusya

\section{ABSTRACT}

As well as being the centre of the governmental body of the State, the Ottoman court also played a significant role in the enhancement of the cultural and artistic life of the court. Traditional funding and encouragement by the court of artists from various fields continued during the $19^{\text {th }}$ century. It is a fact that many European painters were keen on being employed by the Ottoman court and presenting their works to the Sultan. The Polish painter, Stanislaw Chlebowski, was one of those above-mentioned painters. Hired in 1870 as a "court painter" by Sultan Abdulaziz, Chlebowski found that he had the opportunity to bring many years of experience to the Ottoman world. In line with the orders of the Sultan he created a great number of pieces featuring the historic scenes of the city of Istanbul along with the battles and victories of the empire's classical ages. Chlebowski, having gained the appreciation of the Sultan and having acquired an international fame during his tenure, asked for leave and subsequently resigned from his post due to health concerns.

Keywords: Ottoman Court, Istanbul, Sultan Abdulaziz, Painter, Polish, Stanislaw Chlebowski 


\section{Giriş}

Osmanlı saraylarında bilim ve kültür faaliyetlerinin desteklenmesi, sanat ve sanatkârın teşvik ve himâyesi, büyük ölçüde uygulanan geleneğin önemli unsurlarından biridir. Padişahlar tarafından himaye edilen ve itibar gören sanat dallarından birisi şüphesiz ki resim sanatıdır. Gerek saray içinde görevli gerekse saray dışında faaliyet gösteren ve eserlerini sultana takdim eden yerli ve yabancı ressamlar daima taltif ve teşvik edilmiştir. Esasında Osmanlı devlet geleneğinde padişahların en önemli vasıflarından birisi, sanatı ve sanatkârı himaye etmektir. 19. yüzyılda genişleyerek devam eden bu gelenek, padişahların şanlarını da yücelten unsurlar arasında görülmekteydi.

19. yüzyılın ikinci yarısından itibaren İstanbul'un, Avrupalı ressamların ilgi odağı ve bir cazibe merkezi haline geldiğini, bilhassa Avrupalı ressamların saray çevresinde etkin olduklarını belirtmek gerekir. İstanbul'a gelen Avrupalı ressamların resmî dairelerde ve okullarda istihdam edildikleri bilinmektedir. Bu ressamlardan biri Maltalı Joseph (Guiseppe) Schranz'dır. 1832 senesinde İstanbul'a geldiği düşünülen Schranz, 1838'den itibaren Harbiye İdadîsi'nde resim öğretmenliği yapmıştır. Osmanlı asker ressamların yetişmesine katkı sağlayan ressam, padişahın taltifine mazhar olmuştur. İstanbul manzaraları, Boğaziçi görünümleri, günlük hayattan sahneleri yansitan tablolar yapan ressam Joseph Schranz'ın eserlerinden bazıları günümüzde İstanbul Deniz Müzesi Resim Koleksiyonu'nda bulunmaktadır.

İngiliz ressam Sir David Wilkie, 1840'ta Sultan Abdülmecid'in portresini yapmıştır. Yine, 1842'de İstanbul'a gelen ve kolay intibak ettiği bu şehre yerleşmeye karar veren İtalyan ressam Amedeo Preziosi, saraya farklı temalarda tablolar hazırlamıştır. Uzun senelerini bu kentte geçiren ressam, Pera'daki atölyesinde kenti konu alan çok sayıda gravür, günlük hayattan kesitler ve kıyafetlerle ilgili suluboya tablolar yapmıştır. 1867 Paris Uluslararası Sergisi'ne Osmanlı ressamı olarak katılmıştır. Ressam Theodor Aman ise 1854 yılında saraya sunduğu “Oltenitsa Muharebesi” adlı tablosu dolayısıyla taltif edilmiştir'.

Sultan Abdülmecid (1839-1861), yerli ve yabanc1 ressamlara muhtelif resimlerini yaptırdığı gibi, Mühendishane'den yetişen istidatlı gençlerden bazılarını Avrupa'ya tahsile göndererek ihtisas yapmalarına ve yeteneklerini geliştirmelerine imkân verdi. Sultan Abdülaziz (1861-1876) de milli ressamlardan birçoğunu, eğitimlerini tamamlamak amaciyla Avrupa'ya göndermek ve eserlerini almak suretiyle teşvik etti. Ayrıca padişah, saltanatı boyunca muhtelif tarihlerde Avrupa'dan meşhur ressamların tablolarının seçilerek saray için satın alınmasını sağladı ${ }^{2}$ Dolmabahçe Sarayı'nda bulunan tablolardan bazılarını öğrencilerin istifade etmeleri ve yeteneklerini geliştirmeleri için Mekteb-i Harbiye ve Mekteb-i İdadî’ye hediye etti. 1 Şubat 1870 tarihli Takvim-i Vekayi gazetesinde, padişahın on üç adet büyük

1 Bu hususta geniş bilgi için bkz. Fatma Ürekli, Sarayın Son Başressamı Fausto Zonaro İkbâlden İdbâra, Türkiye İş Bankası Kültür Yayınları, İstanbul 2017, s. 6-10.

2 BOA, HH.İ, 56/56; 57/22. 
boy yağlı boya muharebe resimlerini hususi yaveri vasıtasıyla gönderdiği belirtilmektedir. "Pek musanna ve kiymetli tablolar" olduğu vurgulanan bu resimlerden muharebe konulu olanlar Harbiye Mektebi'nde, diğerleri İdadî Mektebi'nde hususi yerlerine merasimle asılmıştır. Merasimde, bütün ümera ve zabitan padişaha teşekkürlerini arz ederek yüksek sesle "Padişahım çok yaşa" duasını yapmışlardır³. Harbiye Mektebi'ndeki tabloların, Birinci Dünya Savaşı sonunda yapılan mütarekeden sonra, binanın İngilizler tarafından işgali nedeniyle Askeri Müze’ye nakledilmesi zaruri görülmüştür'

\section{Sultan Abdülaziz Döneminde Avrupalı Ressamların İstihdamı Meselesi}

Şehzadeliğinde resim dersi alan Sultan Abdülaziz'in, resim sanatına karşı fevkalâde yeteneği ve merakı vardı. Yabancı ressamlara verdiği konuların krokilerini bir iki kalem hareketiyle ve muvaffakiyetle çizebiliyordu․ Sanatkâr kimliğiyle devrin sanat ortamının zenginleşmesinde bir bakıma mihenk taşı olan padişah, yurt içi ve yurt dişı seyahatlerinde maiyetinde genellikle ressamları da bulunduruyordu.

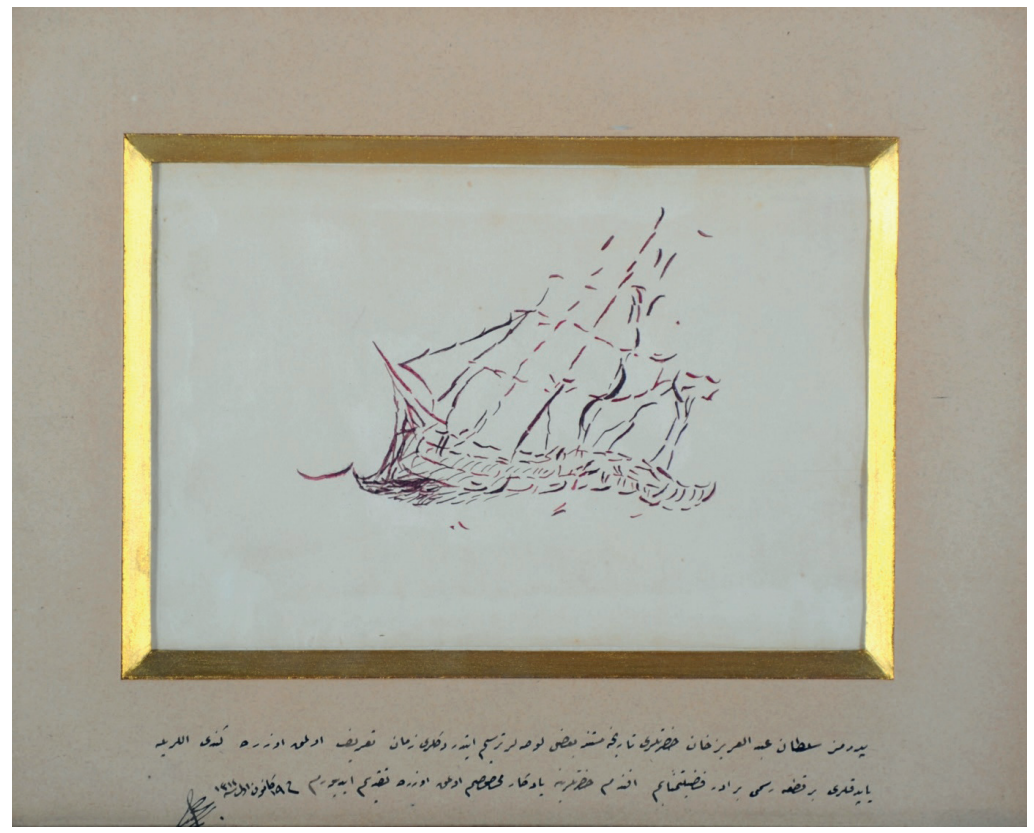

Resim 1

Sultan Abdülaziz, “Gemi Eskizi”, 13 x 19 cm. Resmin altı yazısı:

"Pederimiz Sultan Abdülaziz Han hazretleri tarihe müstenid bazı levhalart tersim ettirdikleri zaman tarif olmak üzere kendi elleriyle yapdıkları bir kut'a resmi birâder-i fazîlet-meâbım efendim hazretlerine yadigâr-ı mahsusum olmak üzere takdim ediyorum 19 Kanun-ı Evvel 1312 (31 Aralık 1896)” (Askerî Müze Resim Koleksiyonu, Env. Nr. 11143).

3 Takvim-i Vekayi, nr. 1183, 29 Şevval 1286.

4 Halil Edhem (Eldem), Elvah-ı Nakşiye Koleksiyonu, İstanbul 1340, s. 29-30.

5 Mehmed Sami, "Selâtinde İncizâb-1 Tersîm”, Osmanlı Ressamlar Cemiyeti Gazetesi, nr. 14, 1 Mart 1330, s. 163. 
Sultan Abdülaziz, sanatı ve sanatkârı destekleyen bir hükümdardır. Padişahın takdir ve ihsanına mazhar olmak ya da sarayda görevlendirilmek arzusuyla eserlerini padişaha takdim etme firsatını elde eden Avrupalı ressamların hemen tamamı taltif edilirdi. 1867'de Sultan Abdülaziz, Fransa İmparatoru III. Napolyon tarafından davet edildiği Milletlerarası Paris Sanayi Sergisi'nin açılışına katılmak üzere Paris'e seyahati sırasında, yakından görme firsatı bulduğu meşhur ressamların bazı tablolarını saray için satın aldırdı. Élysée Sarayı'ndan satın alınan tablolar arasında, meşhur ressam M. Piriz'e ait bir eser de vardı. Bu eseri için ressam, beşinci dereceden Mecidî Nişanı ile mükâfatlandırıldı ${ }^{6}$.

Sultan Abdülaziz'in Avrupa seyahati sırasında Ladislas Paçowski ${ }^{7}$ adında Leh asıllı bir ressam, Viyana'nın kuzeyindeki Klosterneuburg şehrinde padişahı maiyetiyle yansıtan fotoğraflar üzerinden yaptığı resimleri tuğralı ve süslü bir albüm içinde Viyana Elçiliği vasıtasıyla padişaha sunduğunda taltif edildi (Aralık 1867) ${ }^{8}$. Ressamın yazdığ 1 arzuhalde, "Vatanlarından ayrı düşmüş çaresiz Lehlilerin, öteden beri Osmanlı'nın lütuf ve merhametine mazhar olduklarını" vurgulayan sözleri dikkat çekicidir.

Burada hemen şunu hatırlatalım ki, saraya resim sunan veya kendisine nişan verilenler arasında, ressam olarak adını duyurmamış, şöhret bulmamış olanlar da vardı. Maiyetinde bulunduracağı ressamların Avrupa'nın en meşhurları arasından seçilerek getirtilmesini isteyen padişah, bu seçimi genellikle elçilikler vasıtasıyla yapardı. Osmanlı Devleti'nin Avrupa' daki elçilik ve konsolosluklarının, sanatkârların saraya sunmak üzere takdim ettikleri eserleri başkente ulaştırmak ve taltif edilmelerini hatırlatmak gibi sorumlulukları yanında, sarayda istihdam edilecek ressamların en meşhurlarının tespiti ve ön sözleşmenin yapılması gibi görevleri de vardı. Fakat tespit ve tercih edilen her ressamla çalışma şartları ve maaş konusunda kimi zaman kesin uzlaşma sağlanamazdı.

Bu konuyla ilgili yaklaşımların daha iyi anlaşılması açısından bazı misaller verilebilir: 1853 'te Fransız Ressam Janet-Lange ile Paris elçiliği vasıtasıyla müzakere ve şartlar üzerine ön anlaşma yapılarak Mabeyn-i Hümâyûn'a arz edilmişse de ressamın sarayda istihdamı mümkün olmamışt1 ${ }^{9}$. 1869'da sarayda görevlendirilmek üzere yine Ressam Janet-Lange ile irtibat kuran Osmanlı elçiliği, başlatılan müzakereler sonucunda, ressamın yapacağı her resim başına 12.000 frank ve 4.000 frank tazminat verilmesi şartıyla bir anlaşma sağlayarak mukavele yapıldı. Ancak, ressamın üzerindeki sipariş yoğunluğu nedeniyle İstanbul'a gelememesi ve taahhüt ettiği teklifleri yerine getirememesi üzerine, Osmanlı hükümeti yapılan mukaveleyi feshetti ${ }^{10}$.

\footnotetext{
BOA, HR.TO, 78//76.

7 Vatanlarından sürülen Lehlilerden birisinin de kendisi olduğunu ifade eden bu ressam hakkında, aydınlatıcı bir bilgiye henüz ulaşılamadı.

8 BOA, İ.HR, 229/13447; HR.TO, 108/75.

9 BOA, HR.TO, 79/37.

10 BOA, HR.TO, 550/93; Ressam Lange’nin, Kırım Savaşı (1853-1856) dönemine ait pek çok çizimleri vardır: "Oltenitse Muharebesi”, “Gelibolu’da Fransız Askerî Kampı”, "Sivastopol”, “Odessa”, "Potemkin'in Ölümü”,
} 
Bu dönemde, Fransa İmparatoru III. Napolyon tarafindan İstanbul'a gönderilen Ressam Pierre Désiré Guillemet, Sultan Abdülaziz'in portresini yapt ${ }^{11}$. Guillemet de padişahın portresinin yapılması görevinin kendisine verilmesini çok istemekte idi ${ }^{12}$. 1865 yılından itibaren İstanbul'da bulunduğu bilinen başarılı ve verimli çalışmalarıyla padişahın takdirini kazanan Guillemet, saray için çok sayıda resim yapt $1^{13}$. Bilâhare Guillemet, bulunduğu mevkiin avantajından da istifade ile İstanbul' da resim ve mimarlık eğitimi verecek bir okulun kurulmasına teşebbüs etti. Bu hususta 1srarlı çabaları neticesinde hükûmetten resmi izin aldı. Beyoğlu'nda okul için bir yer tahsis edildi ${ }^{14}$.

Ayrıca bu dönemde İstanbul'a gelerek tablolar yapan Rus Ressam Ivan Konstantinoviç Ayvazovski de saray çevresinde öne çıkan sanatkârlardandır. Kırım Savaşı sonrasında 1857 ve 1858 tarihlerinde olmak üzere iki defa İstanbul'a seyahat eden Ayvazovski'ye bu süreçte Dolmabahçe Sarayı için bazı tablolar yaptıran Abdülaziz, ressamı Osmanlı Nişanı ile taltif etti ${ }^{15}$.

$\mathrm{Bu}$ gelişmelere paralel olarak, sarayda görevlendirilmek üzere yetenekli bazı ressamlarla müzakereler de sürdürülüyordu. Saray ressamlığı hizmeti için 1865 'te meşhur ressam Adolphe Yvon ile irtibata geçildi. Paris Elçiliğine davet edilen ressamın yaptığı tablolarından biri 1.000 frank karşılığında satın alınarak İstanbul'a gönderilmişse de sarayda istihdamı mümkün olmadi ${ }^{16}$. Bundan sonra devam eden ressam arayışları sonucunda resimleri ile saray çevresinde kendisini tanıtma imkânı bulan Leh asıllı Rus tebaası ressam Stanislaw Chlebowski tercih edildi. 1864'ün sonunda İstanbul'a gelen ressam, saray için sipariş üzere resimler yapmakta, eserleri için bol ihsanlar almaktaydı.

"Fransız Amiralleri”, "Şâmil'in Naibinin Fransız Kampı'nı Ziyareti”, "Şâmil”in portresinden başka savaş sahneleri de çizmişti (Histoire de la Guerre D’orient Illlustré par Janet-Lange, Éditeur, Gustava Barba, Paris 1854, Muzaffer Ürekli Arşivi).

11 Ruzname-i Ceride-i Havadis, nr. 120, 20 Şevval 1281.

12 Ressam Guillemet'in bu göreve çok isteyerek talip olduğu müracaat dilekçesinden anlaşılmaktadır (BOA, HR.TO, 201/14).

13 Ürekli, Sarayın Son Başressamı, s. 18-20.

14 BOA, HR.TO, 453/74; 58/100; BOA, BEO.NDGGD, Maarif Giden, nr. 395/9-6, 10 Şevval 1290; nr. 58/100, 11May1s 1287; La Turquie, 13-14 Septembre 1874; La Turquie, 29 Juin 1876; İstikbal, nr. 118, 23 Cemaziyelevvel 1293.

15 Fatma Ürekli, “Arşiv Belgeleri Işı̆̆ında Osmanlı Sarayında Nişanlarla Takdir ve Taltif Edilen Ressam Ayvazovski’nin Bilinmeyenleri”, Milli Saraylar Sanat-Tarih-Mimarlık Dergisi/National Palaces Journal of Art-History-Architecture, say1 17 (2019), s. 14-19.

16 BOA, HR.TO, 74/67. 


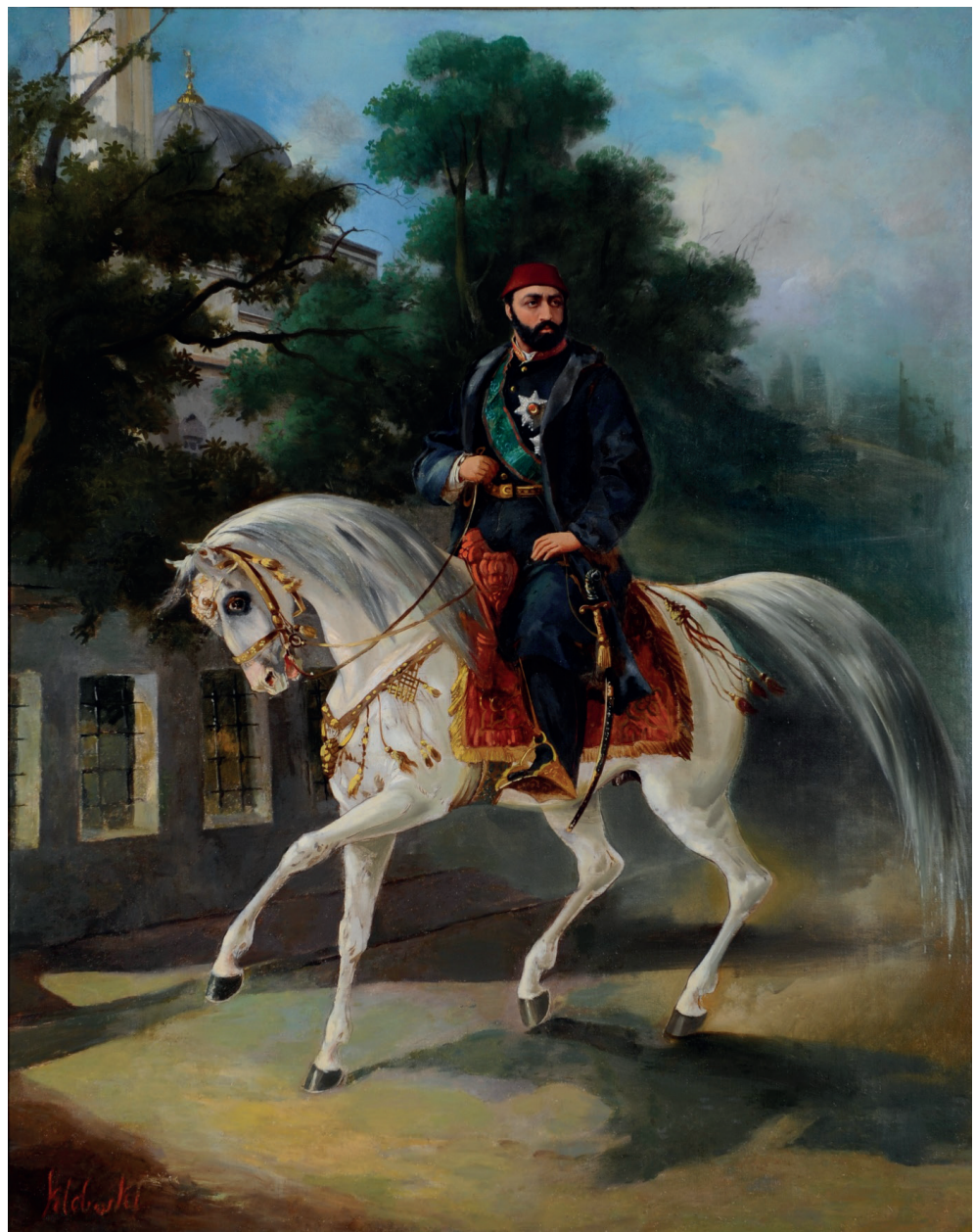

Resim 2

Stanislaw Chlebowski, “Sultan Abdülaziz”, tuval üzerine yağlı boya, 125 x $100 \mathrm{~cm}$, (Askerî Müze Resim Koleksiyon, Env. Nr. 9391).

\section{Saray Ressamlarının Çalışma Mekânı}

Sultan Abdülaziz döneminde, sarayın farklı dairelerinde istihdam edilen yerli ressamların yanında bilhassa seçilerek belirli sürelerle görevlendirilen Avrupalı ressamlar, öncelikle kendilerine verilen siparişleri yerine getirmek ve talepler doğrultusunda eserler üretmekle yükümlüydüler. Hazırladıkları eserler için her defasında bol ihsanlar aldıklarını belirtmek gerekir. Önceleri Saray Musavviri olarak anılan bu vazifeliler, sonraları genellikle Mâbeyn-i Hümâyûn Ressâmı, Sarây-ı Hümâyûn-ı Mülûkâne Ressâmı, Ressâm-ı Hazret-i Şehriyârî ve nihayet Ser-Ressam gibi unvanlar almışlardır. Saraydan aldıkları oldukça yüksek maaşlarının 
dışında, tayinat, elbise ve sair masrafları da hazineden karşılanmaktayd $1^{17}$. Sarayda kendilerine hususi çalışma mekânı tahsis edilen ressamlar, son derece rahat yaşayacakları maddi gelire sahip olmakla birlikte alet ve edevat gibi temel ihtiyaçları da temin edilmekteydi.

Yerli ve yabancı ressamlar, faaliyetlerini Dolmabahçe Sarayı'nın Mâbeyn-i Hümâyûn bölümünde bulunan ve Resim Oda-yı Âlîsi adıyla anılan atölyede sürdürmekteydi ${ }^{18}$. Burada çalışan yerli ressamlardan birisi Es-seyyid Osman Nuri Bey'di. 1863'ten beri saray fotoğrafçısı olarak Abdullah Biraderler de bulunmaktayd $1^{19}$. Bu dönemde, minyatür "tasvir-i hümâyûn" da denilen portreler üzerinde titizlikle çalışılmaktaydı. 1870-1872 yılları arasında, saray ressamı olarak çalışan Stanislaw Chlebowski de resimlerini bu mekânda hazırlamıştır.

Mâbeyn-i Hümâyûn ressamları olarak anılan bu sanatkârların atölyesi için gerekli olan resim malzemeleri ile alet-edevat, İstanbul'daki mağazalardan ve Avrupa'dan, özellikle Paris’ten temin edilmekteydi. Yaldızlı resim çerçevelerinin büyük bir kısmı ile bazı resim malzemeleri İstanbul'da Aleko'nun mağazasından satın alınmaktayd $1^{20}$. Bu işlerle genellikle Ressam Nuri Bey ve Müdür Mustafa Efendi ilgilenmekteydi.

$\mathrm{Bu}$ döneme ait masraf listelerine göre resim atölyesi için ihtiyaç duyulan ve en sık kullanılan malzemeler kurşun kalem, kurşun kalem sapı, resim kâğıdı, resim tezgâhı, resim kömürü, boyalı resim, boya bıçağı, siyah ağaçtan yapılmış resim tezgâhı, ağaç boya tahtası, ağaç el tabağı, resim aletleri kutusu, resim firçası, samurdan resim firçası, yağlı boya boruları, resim muşambası, neft yağı, resim çerçevesi ve boyalı resim ve resim kitapları idi²1.

Serkurena Nevres Paşa, Ziver Bey, İzzet Bey, Mehmed Bey, Fuat Bey ve Hurşit Bey zamanlarında (18 Eylül 1870-22 Şubat 1873 tarihleri arası) ressamların resim malzeme masrafı 96.808 kuruş tutmuştur. 25 Nisan 1874 'te satın alınan muşamba ve yağlı boya masrafı 6.016 kuruş resimci Emanueli’ye, Ceyb-i Hümâyûn'dan es-Seyyid Osman Nuri vasıtasıyla ödenmiştir ${ }^{22}$.

17 Aralık 1861'de, sarayda çalışan ressamların elbise masrafı olarak dört bin üç yüz küsur kuruş ödenmişti (BOA, İ.DAH, 491/33244).

18 T. Cengiz Göncü, "Osmanlı Sarayında Resim Sanatının Himayesinin Simgesi Olarak Resim Odası ve Görev Alan Sanatçılar”, Milli Saraylar Sanat-Tarih-Mimarlık Dergisi, sayı 9, İstanbul, 2012, s. 263-277.

19 Abdülaziz zamanında 1863'ten beri saray fotoğrafçısı olan Abdullah Biraderler, Kevork, Hovsep ve Viçen Abdullah olarak üç Ermeni kardeştir. Viçen Efendi daha sonra Müslüman olmuş ve Abdullah ismiyle anılmaya başlamıştı. "Ressam-1 Hazret-i Şehr-yârî Abdullah Efendi" 1901'de vefat etmiştir (BOA, İ.DAH, 1819/112).

20 BOA, MB, 145/132; Mart 1874’te de resim atölyesi için Aleko'dan alınan malzemeler için 76 lira 3 kuruş Ceyb-i Hümâyûn Hazinesinden ödenmiştir (BOA, MB, 163/214).

21 BOA, MB, 156/100.

22 Yağlı boya masrafi olarak; her biri 9 kuruştan 144 büyük şişe için 1.364 kuruş; her biri 4 kuruştan 144 küçük şişe için 684 kuruş; metresi 50 kuruştan 80 metre muşamba masrafı olarak 4.000 kuruş ödenir (BOA, MB, 163/41); Mayıs 1879'da Beyoğlu'nda resimci Emanueli'ye, iki adet yağlı boyalı resim (1 adet Çiftlik resmi 15 lira, 1 adet İstanbul resmi 8 lira) için Mabeyn-i Hümâyûn'dan 23 lira ödenir (BOA, MB, 163/324). 
Bu dönemde ressamların hazırlayıp takdim ettikleri resimler karşılığında yapılan ödemeler ve ihsanlar, aylık gelir ve giderler, Ceyb ve Harc-1 Hâssa Defterlerine kaydedilmekteydi. Bu defterlerdeki kayıtlarda, resim levhalarının konuları ve ressamı hakkında pek detaylı bilgiler bulunmamaktadir ${ }^{23}$.

Sarayda çalışan ressamlara, bakır üzerine bazı padişahların portreleri de yaptırılmıştır. Osman Gazi'den II. Mahmud'a kadar Osmanlı sultanlarının nuhâs (bakır) üzerine yapılmış portreleri Serkurena Nuri Paşa'nın emriyle Hazine-i Hümâyûn'dan çıkartılarak Mabeyn-i Hümâyûn'a takdim edildikten sonra, Kapı Çuhadarı Nuri Bey vasıtasıyla Hazine-i Hümâyûn'a konulmuştur (5 Şubat 1873) 24 .

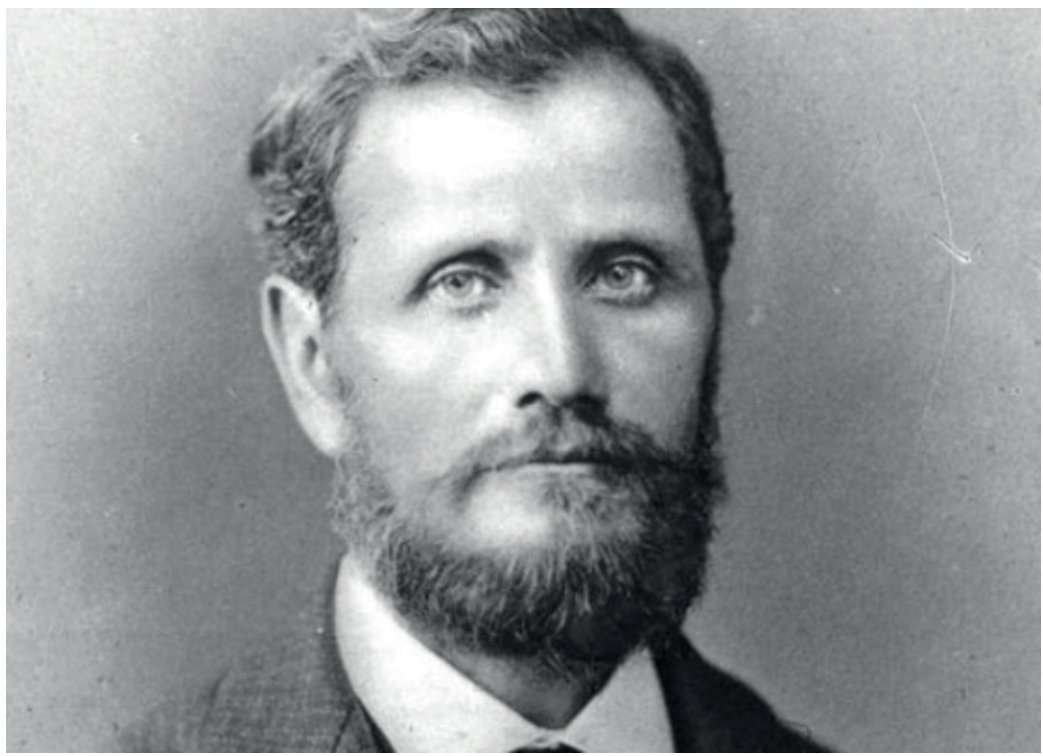

Resim 3

Ressam Stanislaw Chlebowski

23 Bu kayıtlardan birkaç misal vermek gerekirse: 6 adet yağlı boya resim tabloları (1 adet büyük boy, 2 adet orta boy, 2 adet küçük boy resim tabloları), 13 Haziran 1871; 7 adet yağlı boya resim tabloları (5 adet büyük boy ve 2 adet küçük boy), Şubat 1872; 7 adet yağlı boya resim tablosu: 5 adet büyük boy ve 2 adet küçük boy yağl1 boya resim tabloları; Elvan boyalı 44 adet Fransız asker neferinin çerçevesiz resimleri ile 1 adet karakalemle yapılmış Napolyon'un muharebesini tasvir eden siyah boyalı tahta çerçeveli resimler, 6 Kasım 1872; yağlı boya ile yapılmış tahta çerçeveli, 3 adet büyük boy muharebe resim tablosu, 12 Şubat 1873 (BOA, TSMAD, 00402.0004.00.002; TSMAD, 00402.012.002; TSMAD, 00348.0001.00.001; TSMAD, 00401.0004.003).

24 Bakır üzerinde yazı olduğu belirtilen bu resimlerle ilgili kayıt şöyledir: "Ser-kurena Nuri Paşa emriyle Hazine-i Hümâyûn-ı Şahâneden bil-ihraç kapu çuhadarı Nuri Bey vasıtasıyla Mabeyn-i Hümâyûn-ı Mülûkâneye takdim olunan Sultan Osman Han Gazi Hazretlerinden, Sultan Mahmud Han-ı Sani Hazretlerine kadar selâtin-i âl-i Osman Hanın nuhâs (bakır) üzerine tersim kılınmış resm-i hümâyûnları, 5 Şubat 1873 'te Kapu Çuhadarı Nuri Bey yediyle gelip Hazine-i Hümâyûna vaz'olunmuştur. Nuhâs üzerinde yazı muharrerdir" (BOA, TSMAD, 00379.0001.003). 


\title{
Ressam Stanislaw Chlebowski’nin İstanbul'a Geliși ve İlk Yılları
}

Yaygın şekilde Stanislaw Chlebowski (1835-1884) olarak bilinen Leh Asıllı Rus tebaası ressamın adı, Osmanlı belgelerinde "Hleboski", "Kleboski”; Rusça kaynaklarda ise "Stanislav Hlebovskiy” olarak geçmektedir. Petersburg Güzel Sanatlar Akademisi’ndeki eğitim yıllarında yaptığı ilk resimlerinde, "S. Hlebovskiy" imzasını kullanmıştır²5. 18691878 yılları arasında tespit edilen tablolarındaki imzası ise "St. Chlebowski", "St. Ch" şeklindedir. Günümüzde Rusya ve Ukrayna'da, ressamın adı Stanislav Hlebovskiy olarak telaffuz edilmektedir.

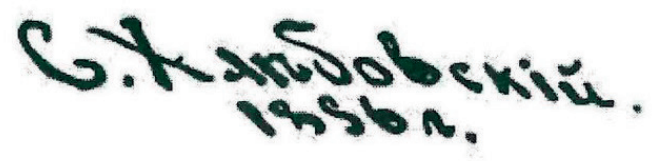

\section{1. Хлебовсквй, Ставислав}

\author{
Resim 4 \\ Chlebowski'nin akademi öğrenciliği sırasında kullandığı imzası \\ (Ruskie Hudojniki XVIII-XX Vekov Spravoçnik, Moskova 2005, s. 312).
}

Chlebowski, bugün Ukrayna'nın Hmelnitski bölgesinde kalan, o günkü Çarlık Rusya'nın Podolsk eyaleti Pokutintsa köyünde 1835 Nisanında doğdu. Bir öğretmen ailesinin çocuğu olan Chlebowski'nin çizime olan ilgisi erken yaşlarda fark edildi. 1853 yılına kadar yaşadığı Odessa'da, Odessa Resim Okulu'nda A. Viherski ve Romuad Hoynadskiy'den ilk resim eğitimini aldı. Ardından, sanat eğitimine 1853-1859 yılları arasında Petersburg İmparatorluk Sanat Akademisi'nde devam etti. Kabiliyetli genç akademi öğrencisi Chlebowski, eğitim çalışması olarak yaptı̆̆ı "Genç Bassuet, Markiza Rambuelya'nın Evinde Vaaz Veriyor"26 konulu resmi için gümüş madalya (1857); “Büyük Petro 'nun Huzurunda Teşrifat” adlı tasviri için altın madalya ile ödüllendirildi $(1858)^{27}$.

Chlebowski, akademi bitirme tezi olarak yaptığı “Imparatoriçe II. Katerina'nın Zaparojili Elçileri Kabulü” adlı tablosuyla eğitimini tamamlamış ve 1859'da mezun olmuştur. Bu tablo için ressama altın madalya verilmiştir ${ }^{28}$. Ayrıca, "Janr (tür) Ressamı” payesi verilen ressam,

251856 yılına ait "S. Hlebovskiy" imzası için bkz. Jivopis XVIII-Naçala XX Veka (Do 1917 Goda), Moskova 1952, s. 729; Vladimir Daniloviç Solovyev, "Hlebovskiy Stanislav (1835-1884)", Ruskie Hudojniki XVIII-XX Vekov: Spravoçnik, Moskova 2005, s. 312.

$26 \mathrm{Bu}$ tablo bugün, Tretyakovskiy Devlet Resim Galerisi'nde bulunmaktadır. Müteakiben yaptı̆̆1 "Prens Oranskiy'nin Ölümü, 1861 ” adlı tablosu ise Arhangels Görsel Sanatlar Müzesi'ndedir.

27 www.stydiai.ru/21.12.2019.

28 Sergey Nikodimoviç Kondakov, Yubileynıy Spravoçnik Imperatorskoy Akademii Hudojestv 1764-1914, Tom II, St. Petersburg 1915, s. 211; Vladimir Daniloviç Solovyev, "Hlebovskiy Stanislav (1835-1884)", Ruskie Hudojniki XVIII-XX Vekov: Spravoçnik, Moskova 2005, s. 312; www.stydiai.ru/21.12.2019. 
yurt dışı seyahati için para ikramiyesi ile ödüllendirildi. Böylece; Fransa, Almanya, Belçika, İspanya ve İtalya'ya seyahat eden Chlebowski, Münih’te Güzel Sanatlar Akademisi'nden sonra Paris'te ihtisasına devam etti. Paris'te Jean Leon Gérôme'un stajyeri oldu. Ressam, buradaki ilk başarısını, III. Napolyon'un devlet koleksiyonu için satın aldığı “Jeanne d'Arc (Jan Dark)' $\imath$ Hapiste” tasvir ettiği tablosu ile elde etti. Ressamın bu dönemde yaptığı resimlerden öne çıkanlar ise, "Ressamın Atölyesinde” (1861), "Sahne” (1863) konulu tablolarıdır29. Aynı zamanda suluboya tekniğinde de çalışan ressamın, 1862'den itibaren Güzel Sanatlar Akademisi emeklisi olduğuna dair bir malumat bulunmakla birlikte bunun teyide ihtiyacı vardır ${ }^{30}$.

1864'ün sonunda İstanbul'a gelen ressam, 1876 senesi sonuna kadar İstanbul'da yaşadı. Chlebowski'nin, eserlerinin Abdülaziz'in ilgisini çekmesi üzerine padişahın daveti ile İstanbul'a geldiğine dair bilgiler varsa ${ }^{31}$ da bunun doğruluğu henüz kesinlik kazanmamıştır. Seraskerlik makamı uhdesinde bulunan Sadrazam Keçecizâde Fuad Paşa'nın ${ }^{32}$ isteği ile askerî ve savaş sahneleri resmetmek üzere davet edildiği belirtilmektedir. İstanbul'a geldiğinde, ressama padişah ve askerî ricali gösteren resimler 1smarlandığı ve Fuad Paşa tarafindan padişaha tanıtıldığı anlaşılmaktadır ${ }^{33}$. Bir başka bilgiye göre, Fuad Paşa'ya ressamı tavsiye edenin Polonyalı mühtedi, Osmanlı ordusuna bağlı Kazak Süvari Alayı'nın kumandanı ve sarayda nüfuzlu olan Sadık Paşa (Michal Czajkowski) olduğudur ${ }^{34}$.

Ressamın beğenilen iki yağlı boya taslağı Abdülaziz'e gösterildikten sonra padişah, ressamı Beylerbeyi Sarayı için bazı tablolar yapmakla görevlendirdi (1865). Sipariş edilen bu tablolar tamamlanınca, 1 Nisan 1865 'te bir hafta boyunca Galatasaray Kışlası'nda sergilendi, ardından Beylerbeyi Sarayı'na taşınarak ait olduğu mekâna yerleştirildi ${ }^{35}$.

Aldığı siparişlerden epey para kazanan ve her resim karşılığında kendisine yüksek ücret ödenen Chlebowski, yine de ekonomik sıkıntı içindeydi. Zira 1863’teki Rus karşıtı Ocak

29 Eduard Gavriloviç Konovalov, Slovar Russkih Hudojnikov: Novıy Polnıy Biografiçeskiy, Moskova 2008, s. 500-501; www.stydiai.ru/21.12.2019.

30 Vladimir Daniloviç Solovyev, "Hlebovskiy Stanislav (1835-1884)", Ruskie Hudojniki XVIII-XX Vekov: Spravoçnik, Moskova 2005, s. 312;

31 "Stanislaw Chlebowski”, Polonya Sanatında Oryantalizm, Pera Müzesi Yayınları, İstanbul 2014, s. 331.

32 Sultan Abdülaziz tarafından sadrazamlığa getirilen (22 Kasım 1861) Fuad Paşa'nın ilk işi, büyük bir buhran içinde olan Osmanlı maliyesinin düzeltilmesi için gerekli bazı tedbirleri almak olur. Hazinenin kontrolünü bizzat üstlenerek gayret göstermesine rağmen maliyeyi hedeflediği gibi düzeltememesi, durumun giderek ağırlaşması üzerine sadaretten ayrılır (2 Ocak 1863). Bir süre sonra seraskerlik uhdesinde kalmak üzere ikinci defa sadrazam olur (1 Haziran 1863). Üç yıl sonra padişah tarafından bu görevden alınarak Hariciye Nazırlığı görevine getirilir (Şubat 1867). Abdülaziz'in Avrupa seyahatinde yanında bulunan Fuad Paşa, hastalığının giderek ilerlemesi sonucu 12 Şubat 1869'da vefat eder (Orhan F. Köprülü, "Fuad Paşa, Keçecizâde (18151869)", Di்A, XIII, 1996, s. 203).

33 Mary Roberts, İstanbul Karşılaşmaları, Osmanlılar, Oryantalistler ve 19. Yüzyıl Görsel Kültürü, çev. Zeynep Rona, İş Bankası Kültür Yayınları, İstanbul 2016, s. 54.

34 Agata Wójçik, "Stanislaw Chlebowski, Sultan Abdülaziz’in Sarayında", çev. Nazan Erbil, Milli Saraylar Sanat-Tarih-Mimarlı Dergisi/National Palaces Journal of Art-History-Architecture, say1 17 (2019), s. 34.

35 Roberts, İstanbul Karşılaşmalarl, s. 58-59. 
Ayaklanmasına $^{36}$ katıldıkları için annesi ve kız kardeşinin malvarlığına Rus yetkililerce el konulmuştu. Sibirya’ya sürülmeleri söz konusuydu.

Bu süreçte, ailesini sürgünden kurtarmak için çareler arayan ressam, Sultan Abdülaziz'in himayesini ve saray çevresiyle olan ilişkilerini kullandı. Nihayet 1866 Ekim'inin ortalarına doğru, yakınlarını Odessa'dan İstanbul'a getirtmeyi başardı. İstanbul'da bir süre yaşayan ailesi, daha sonra temelli olarak Krakow'a gitti.

Chlebowski ise bu dönemde aldığı büyük ve kârlı siparişler dolayısıyla İstanbul'da kalmaya devam etti ${ }^{37}$. Pera'ya yerleşerek Eylül 1871'e kadar Sıraselviler'deki atölyesinde çalıştı. Akabinde aynı semtte Ağa Hamamı Sokağı'nda taşındığı kiralık evini hem ikamet hem de atölye olarak kulland1 ${ }^{38}$.

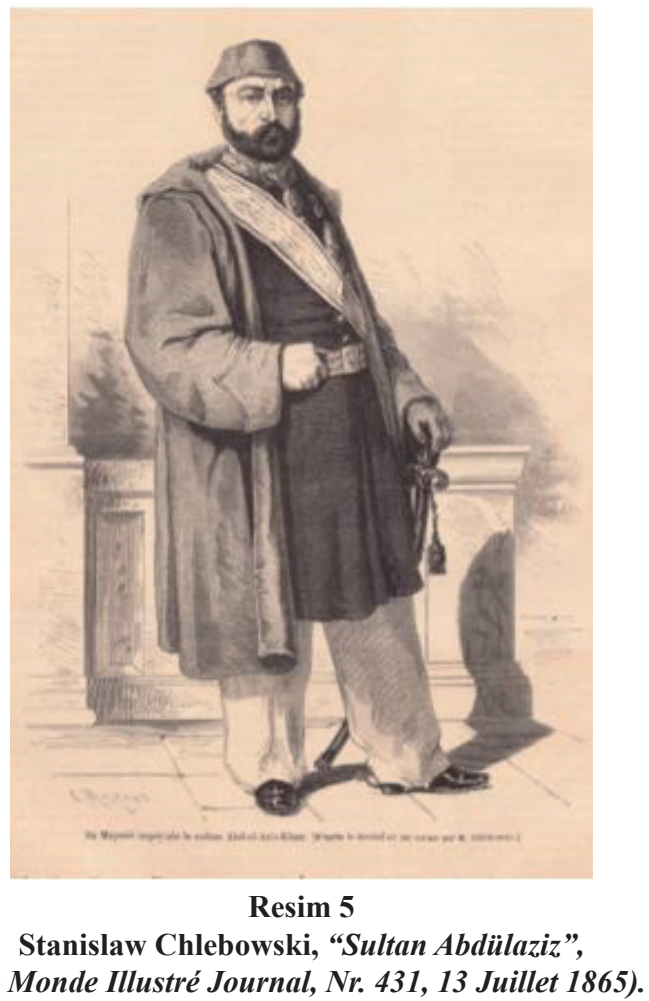

36 Lehistan'ın bağımsızlığı için 1863 'te başlayan ve önemli bir dönemeç olarak bilinen Leh millî hareketi “Ocak Ayaklanması” olarak anılmaktadır. Bütün Doğu Avrupa ülkelerine yayılan ve Rusya’ya karşı oluşturulan bu isyan, 1865 'e dek sürmüştür. Bu geniş coğrafyalı ayaklanma esnasında Lehlilerin destek arayışlarının bir merkezinin de İstanbul olduğunu belirtmek gerekir. Avrupa'da geniş yankı bulan bu isyan hareketi, sert müdahaleler ve ağır cezalandırmalara rağmen Rusları bir yıldan fazla uğraştırdı. Bu hareketin önderlerinin konumları, müsadereler yoluyla ekonomik yönden zayıflatıldı.

37 Wójçik, "Stanislaw Chlebowski, s. 34.

38 Wójçik, "Stanislaw Chlebowski, s. 36. 
Le Monde Illustré Journal, Chlebowski'nin 1865'te çizdiği Sultan Abdülaziz portresine yer vermektedir ${ }^{39}$. Ressamın bir başka çiziminin reprodüksiyonu, L'Illustration Journal Universal'da, “Eugenié'nin İstanbul Seyahati, Sultanın Diplomat Heyetini Beylerbeyi Sarayı'nda Karşılaması, 1869”” açıklaması ile yayınlandı ${ }^{40}$. Bu çizim, III. Napolyon'un eşi İmparatoriçe Eugénie, Süveyş Kanalı'nın açılışına giderken İstanbul'a seyahati sırasında yapılmıştır. Resimde, Beylerbeyi Sarayı'nda Eugénie, maiyetindekileri padişaha takdim etmektedir; ortada padişah ve imparatoriçe, çevresinde hizada duran maiyetleriyle tasvir edilmiştir.

İstanbul'da bulunduğu günlerde Şeyh Şâmil ve büyük oğlu Gazi Muhammed ile karşılaşan Chlebowski, onların portrelerini de yapma firsatı buldu.

\section{Şeyh Şâmil ve Oğlunun Portrelerini Yapması}

Bir Nakşibendî şeyhi olan Şâmil (1797-1871) lider (imam) seçildikten sonra kararlı tutumu, askerî ve siyasî dehasıyla Dağıstan'da ve bütün Kafkasya'da idarî ve dinî otorite sayılmıştı. Şeyh Şâmil 1859'da Ruslarla mücadele ettiği sırada, oğulları Gazi Muhammed ve Muhammed Şâfîi ile birlikte teslim olmak zorunda kaldı. Rusların uzun zamandır direnişini kırmaya çalıştıkları Şâmil'e iyi muamelede bulundukları bilinmektedir. Saint Petersburg'tan sonra Kaluga'ya götürülen Şeyh Şâmil, Çar Aleksandr ile görüşmesini müteakip kendi isteğiyle Kiev'e geçti (1869).

Bu esnada, Şeyh Şâmil'in çok arzu ettiği kutsal yerleri ziyaret etme yani Hac ibadetini yerine getirme isteği Çar tarafından kabul edildi. Böylece Şâmil'e, oğullarını Rusya'da bırakmak ve geri dönmek şartıyla Hacca gitme müsaadesi verilince, diğer aile üyeleriyle 31 Mayıs 1869 tarihinde önce İstanbul'a geldi. Burada coşkulu şekilde karşılanan Şâmil, önce sadrazam, şeyhülislâm ve dâhiliye nâzırını ziyaret etti. Ardından, Sultan Abdülaziz tarafından Dolmabahçe Sarayı'nda kabul edildi (15 Ağustos 1869). Padişah, Şeyh Şâmil'e ve aile fertlerine maaş bağlattı ve özel konut tahsis etti. Yedi ay Koska'da kendisine ayrılan köşkte ikamet eden Şâmil, Sultan Abdülaziz'e bir veda ziyaretinde bulunduktan sonra, 25 Ocak 1870'te Mekke'ye gitmek üzere İstanbul'dan ayrıldı. Hac görevini ifa ettikten sonra bir daha dönmeyerek Medine'ye yerleşen Şeyh Şâmil, 4 Şubat 1871 'de burada vefat etti ${ }^{41}$.

39 Le Monde Illustré Journal, nr. 431, 13 Juillet 1865, s. 46.

40 L'Illustration Journal Universal, Tome LIV, Décembre 1869, s. 309.

41 Mustafa Budak, "Şeyh Şâmil”, DİA, XXXIX, 2010, s. 67-70. 


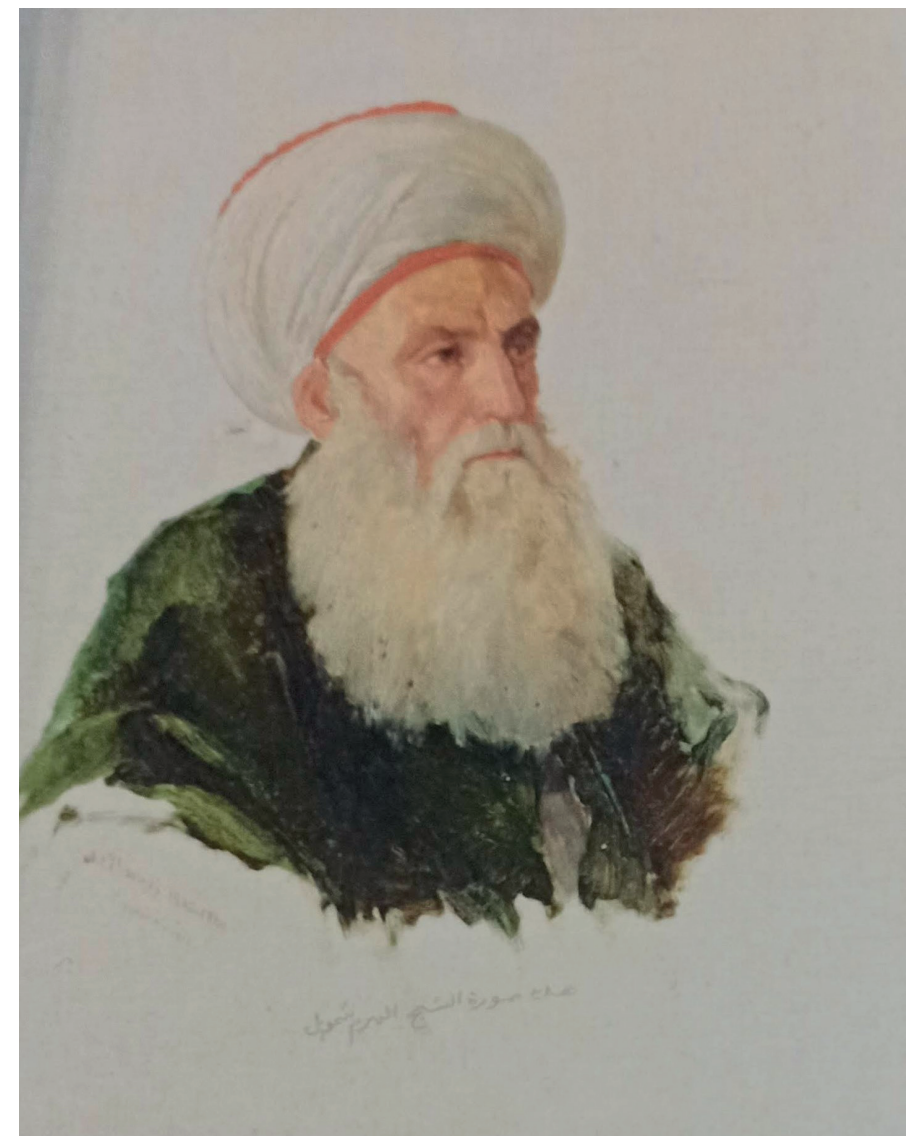

\section{Resim 6}

Stanislaw Chlebowski, "Şeyh Şâmil'in Portresi”" 48 x $40 \mathrm{~cm}$.

Resmin Sol alt köşesinde "St. Chlebowski 18 Aout 1869 Constantinopole" imzası vardır (Livov Resim Galerisi, Env. Nr. J-382. Galeriye B. Ojehoviç’ten satın alınmıştır).

Şeyh Şâmil'in hastalığı ile ilgili haberin Rusya'ya ulaşması üzerine Çar, Şâmil'in oğlu Gazi Muhammed'e, babasını ziyaret etmesi için izin verdi. Aynı yolu takip ederek İstanbul'a ulaşan Gazi Muhammed, birkaç gün kentte konakladıktan sonra babasının yanına gitmek üzere ayrıldı. Babasının vefatından sonra Gazi Muhammed Rusya'ya dönmeyerek Osmanlı ordusu hizmetine girdi. 1877-1878 Osmanl1-Rus Savaşı'nda Ruslara karşı savaştı. 


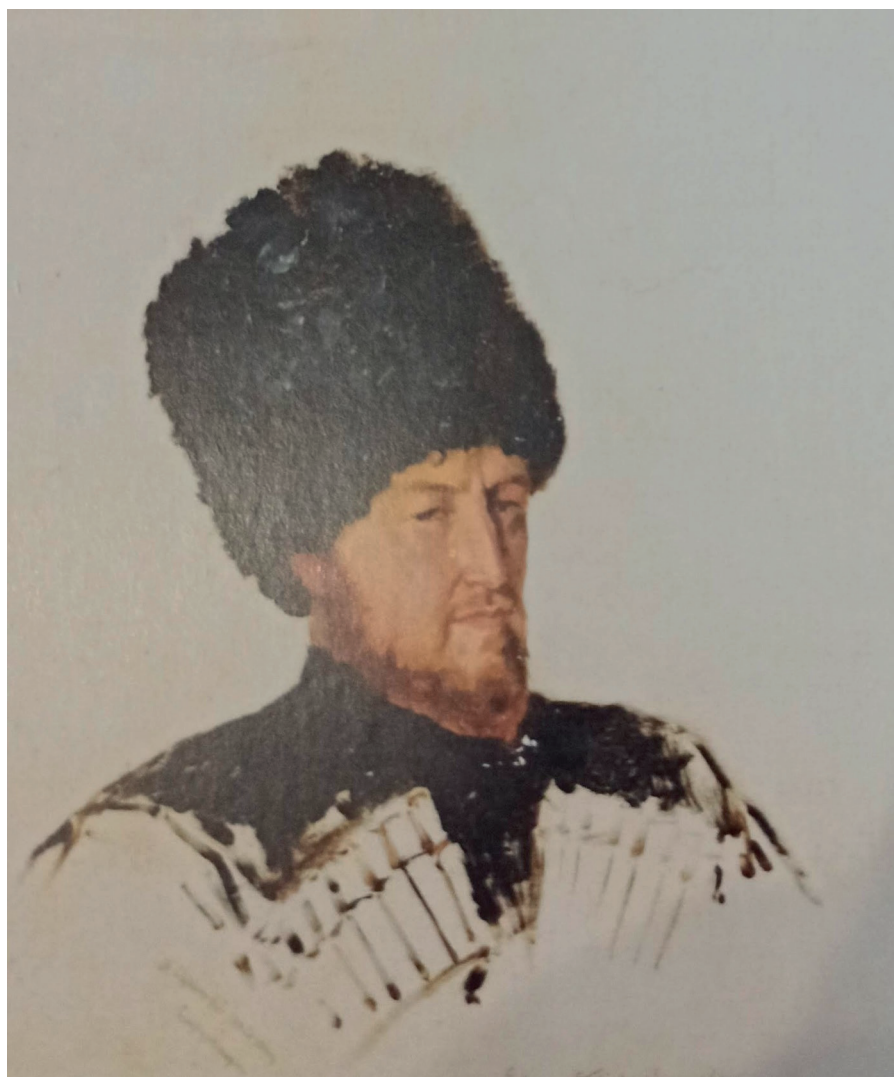

Resim 7

Stanislaw Chlebowski, "Şeyh Şâmil’in Oğlunun Portresi”, 48 x 40 cm. Resmin sol alt köșesinde "St. Chlebowski 18 Aout 1869 Constantinopole" imza ve tarihi vardır (Livov Resim Galerisi, Env. Nr. J-381. Galeriye B. Ojehoviç’ten satın alınmıştır).

Chlebowski, Şeyh Şâmil ve oğlu Gazi Muhammed'in İstanbul'da bulundukları günlerde portrelerini yapma firsatını kaçırmadı ${ }^{42}$. Ressamın imzası bulunan bu portreler günümüzde, Livov Resim Galerisi'ndedir³. Böylece, Rus İmparatorluğu'nun güçlü orduları karşısında unutulmaz destansı bir mücadele veren Şeyh Şâmil'in adı, Rus işgaline karşı direnen Kafkas kavimlerinin hafızasına nakşedildiği gibi, Chlebowski’nin resmettiği bu portrelerle de o devrin birer şahidi olarak ebedileşmiştir.

42 Hadji Murad Donogo, Pobedit Tot, Kto Vladeet Kavkazom, Miniaturı Kavkazkoy Voynı 1817-1864, Moskova 2015, s. 269-270.

43 Shid u Tvorçesti Evropeyskih Hudojnikiv Albom Katalog, Lviv 2008, s. 34. 


\section{Mabeyn-i Hümayûn Ressamı Stanislaw Chlebowski}

Sultan Abdülaziz, eserlerini takdir ettiği Stanislaw Chlebowski’yi, 21 Eylül 1870’de “Mabeyn-i Hümayûn Ressamı" olarak görevlendirdi. Dördüncü dereceden Mecidî Nişanı14 ile taltif ettiği ressama, Ceyb-i Hümâyûn hazinesinden aylık 5.000 kuruş maaş bağladis ${ }^{45}$. Padişahın talepleri istikametinde yoğun bir çalışma temposu içerisinde resimler hazırlayan Chlebowski, bir taraftan da üç şehzadeye resim dersleri verdi.

Sultan Abdülaziz'in pek çok sanatkârı teşviki amacıyla atiyye-i seniyye şeklinde ödediği ihsanlardan Ressam Chlebowski'ye de çeşitli vesilelerle verildi. Genel olarak yaptığı her tablo için verilen ücret miktarı, ayrıca ihsan olarak verildi. Farklı zamanlarda olmak üzere bu çerçevede kendisine toplamda 250 bin kuruş ödendi. Chlebowski'nin, padişaha yaptığ her resmi takdim ettiğinde aldığı ihsan, diğer ressamlara verilen miktarın yaklaşık iki katı kadardır. Serkurena Nevres Paşa'nın döneminde, Ressam Nuri Bey’e verilen ihsanlar buna misal olarak gösterilebilir. 13 Aralık 1870'te 5.000 kuruş; 19 Ocak 1871 'de 5.000 kuruş, 13 Aralık 1870'te gemi resmi için 5.000 kuruş; ayrıca ihsan olarak 5.000 kuruş verilir (13 Kasım 1870); zırhlı gemi resmi için ise 2.500 kuruş (18 Şubat 1871) olmak üzere toplamda 22.500 kuruş Nuri Bey’e ödeme yapıldı.

Yaptığı minyatür portrelerin Osmanlı sarayından bazı Avrupalı hükümdarlara hediye olarak gönderilmesi, ressamın uluslararası alanda tanınması ve ününün yayılmasına vesile oldu. Kendisine, Almanya, İtalya, İspanya ve Belçika'dan madalya ve nişanlar verildi ${ }^{46}$.

\section{Saray Ressamlığından Ayrılışı}

Clebowski'nin askerî konulu resimlerinin çoğunun, padişahın çizdiği ya da hazırladığı taslaklardan hareketle yapılmış oldukları bilinmektedir. Mehmed Sami (Yetik), padişahın ressamı yönlendirdiğini şöyle anlatır:

"Stanislaw Chlebowski saraydaki daire-i mahsûsada müddet-i medide çalıştırılmış mazinin hatırat-ı muzafferiyetini tasvir maatteessüf bu firçaya müyesser olmuştur. Tabloların bir kısmını tetkik edebildiğim için söyleyebilirim ki bunlar sanat nokta-i nazarından diğer şaheserler yanında pek sönüktür. Değerli bir firça mahsulü değildirler. Fakat kıymet-i tarihiyye itibariyle pek ehemmiyetlidir. Kurenâ-yı sabıkadan bir zat tarafindan yedi sekiz sene evvel dinlemiştim. Merhum Abdülaziz, ekser tabloların kompozisyonunu eskizmüsvedde suretinde kâğttlara hazırlayarak ressamın fikr-i tasvirini esas levha hakkında tenvir ederlermiş. Bir gün Abdülaziz, Chlebowski'nin tablosundaki kompozisyona itiraz ederek çizgileri tashih etmişler. Ressam anlaşılan kendi fikirlerine muhalif gördü̈̆̈̈ bu tashihâtı İstanbul'da bulunan Sokolovoski'ye göstererek şikâyet etmek istemişse de tashihâtın doğru olduğunu öğrenince tesellüm-i hakikate mecbur olmuştur"'47.

44 BOA, İ.DAH, 612/42650.

45 BOA, MB.İ, 23/129.

46 Wójçik, "Stanislaw Chlebowski, s. 41-42.

47 Mehmed Sami, "Selâtinde İncizâb-1 Tersîm”, Osmanlı Ressamlar Cemiyeti Gazetesi, nr. 14, 1 Mart 1330, s. 163. 
Saraydaki yoğun çalışmalarının ardından tekrar saraya çağrılıp padişahın emirleri doğrultusunda resimlerinde düzeltmelerin istenmesi ressamı oldukça bunalttı. İki sene çalıştıktan sonra saraydan ayrılmaya karar verdi. Ailesine yazdığı mektubunda, Sultan için çalışmayı "hapiste olmak", hatta "ruhunu sultana satmak" şeklinde ifade etmesi, çalışma şartları ve saray ortamından memnuniyetsizliğini yansıtmaktadır ${ }^{48}$. Tüm günlerini yoğun çalışma içinde geçirdiğini, bu sebeple sağlığının bozulduğunu vurgulayan ressam, saraydan ayrılmak niyetinde olduğunu ve geleceği için yeni planlar yaptığını belirtir. Padişahın iltifat ve teveccühüne mazhar olduğunu vurgulamakla birlikte, çevresinde kendisini çekemeyenlerin bulunduğunu düşünür ${ }^{49}$.

Ayrıca, Osmanlı Devleti'nin malî durumunun bozuk olduğuna dikkati çeken ressam, pek çok görevlinin maaşlarının ödenmediğini, mabeyincilerin görevden alındığını ve sarayda istikrarın sağlanamadığını belirtir.

Gerçekten de Sultan Abdülaziz'in tahta çıkışından itibaren, saltanatı boyunca karşılaşılan en büyük güçlüklerden birisi malî sıkıntı idi. İlk yıllarda Tanzimat devrinin en yetenekli idarecilerinden olan Âlî Paşa ve Fuad Paşa'nın tedbirleri neticesinde ekonomik kriz ötelenebilmişse de 1871 yılından itibaren giderek malî buhran had safhaya ulaşmıştı. Avrupa ülkelerinden üst üste on bir defa borç alınmıştı. Devletin harcamalarının finansmanında borçlanma yöntemine başvurulması, giderek vadesi gelen borçları dahi yeni borçlanmalarla kapatma politikasına dönüşmüş ve bu politikanın iyi yönetilememesi, hazineyi iflasın eşiğine getirmişti ${ }^{50}$.

Dönemin ekonomik sıkıntıları içinde, ressamın maaşlarının pek aksamadan ödendiği, resim malzemelerinin tedarik edildiği gibi masraflarında bir kısıtlama yapılmadı̆̆ı hesap pusulalarından tespit edilmektedir. Hâl böyle iken Chlebowski iki sene süren saray ressamlığı görevinden sağlık sorunlarını bahane ederek, elindeki siparişleri bile tamamlamadan 21 Eylül 1872 'de istifa etti ve maaşı kesildi ${ }^{51}$.

Abdülaziz'in yapmasını istediği resimleri tamamlamayı beklemeden saraydan ayrılan ressam, İstanbul'da yaşamaya devam ederek atölyesinde resimler yaptı. Padişahın siparişi olan ve hazırlayamadığı resimlerden birisi de “II. Mehmed'in İstanbul'a Girmesi” konuludur.

1873 'te Kahire'yi ziyaret eden ressam, yoğun talepler üzerine burada birçok yağlı boya ve sulu boya tablo yaptı. İstanbul'a dönüşünü müteakiben, Viyana, Dresten, Paris ve Krakov’u kapsayan bir Avrupa seyahati yapt1 ${ }^{52}$.

48 Wójçik, "Stanislaw Chlebowski", s. 49.

49 Wójçik, "Stanislaw Chlebowski", s. 37-38.

50 Cevdet Küçük, “Abdülaziz”, ḊंA, I, 1988, s. 183.

51 BOA, MB.İ, 27/85.

52 www.stydiai.ru/21.12.2019. 
Ressamı saraydan ayrılmaya zorlayan asıl sebep hastalık olmayıp, yukarıda da değinildiği gibi yoğun çalışma şartları, eserlerine padişahın fazlaca müdahalede bulunmasına sabır ve tahammül gösterememesi yanında, saray ortamındaki ilişkilerden duyduğu tedirginliktir.

Öte yandan, Chlebowski'nin saray ressamlığ görevinden ayrılmasından sonra, onun yerine yeni ressam arayışlarına devam edildi. Avrupalı ressamlardan bazıları ile irtibat kuruldu. Paris Güzel Sanatlar Okulu'nda çalışan meşhur ressam Adolphe Yvon ile görüşüldü. Çünkü Yvon, senelik 80 bin frank maaşla muallim olarak çalıştığı işinden ayrılarak sarayda çalışmak istediğini Osmanlı'nın Paris elçiliğine iletmişti (Mart 1873). Osmanlı sarayında çalışmak için Ressam Yvon'un ileri sürdüğü şartları şöyleydi: İki sene müddetle mukavele yapılacak, ayda 12.500 frank maaş verilecek ve senede altı hafta izinli sayılacak, şayet iki seneliğine yapılan bu mukavele, vaktinden önce feshedilirse senelik maaşının yarısı tutarında kendisine tazminat ödenecekti. Ayrıca, elinde sipariş olarak aldığı 40.000 franklık resimleri tamamlayamadan yarım bırakıp İstanbul'a gideceğinden, bunun için kendisine münasip miktarda tazminat verilecektir ${ }^{53}$.

Müzakere neticesinde ressam ile mukavele yapıldı. Fakat Yvon, elindeki işleri tamamlamak için kendisine dört ay daha ek süre verilmesini de isteyince, kendisiyle yapılan mukavele feshedildi.

Akabinde usta bir ressam olan Armand-Dumaresq'in istihdamı düşünüldü. Paris elçiliği vasitasıyla ressamla irtibat kuruldu (Ekim 1873). Dumaresq’in hünerli bir ressam olduğunu vurgulayan Paris Elçiliği, genellikle deniz olayları ve savaşlarını tasvir ettiğini, sanatında "maharet-i kâmilesine nazaran muktedir" bulunduğunu beyan eder. Takdim olunan resimlerin, görüldükten sonra sahibine iade edilmek üzere tekrar gönderilmesi istenir. Ayrıca ressamın teklif şartları üzerinde müzakereye başlamak için açık emir beklenildiği hususu Hariciye Nezareti'ne hatırlatılır.

Ressam ile bir uzlaşma sağlanamayınca 1874'te Ressam Rendleman ile görüşülerek sarayda görevlendirilmesi istenir. Paris elçiliği, ressamla bir ön anlaşma yapar ve numune olarak iki tablosunu İstanbul'a gönderir. Bu esnada Adolphe Yvon, sarayda görev almak için Paris elçiliğine tekrar müracaat etmişse ${ }^{54}$ de kendisine bir görev verilip verilmediği hususunda henüz kesin bir bilgi yoktur.

\section{Chlebowski’nin Resim Masraflarına İlişkin İddia ve Talepleri}

Rusya Sefareti ile sıkı ilişkiler içinde bulunan Chlebowski, saraydan ayrıldıktan yedi ay sonra ressamlık hizmeti süresince yaptığı resimler ve levazımat masraflarının kendisine

53 BOA, HR.TO, 119/42.

54 Ürekli, Sarayın Son Başressamı, s. 11. 
eksik ödendiği iddiasında bulundu. Bu husustaki arzuhali ve masraf pusulaları Rusya Sefareti vasıtasıyla Mabeyn-i Hümâyûn Başkitabeti’ne iletildi.

Chlebowski, 2 Mayıs 1873 tarihli arzuhalinde 55 "Mabeyn-i Hümâyûn Ressamı" unvanıyla fedakârca hizmette bulunduğunu, bu süreçte padişahın iltifat ve ihsanlarına nail olduğunu belirttikten sonra, yaptı̆̆ 1 resimlerin masraflarının bir dönem kendisine verilmediğini beyan etmiştir. Her bir resim tamamlandığında malzeme masrafları ile ayrıca üstadiyyesinin kendisine ödenmesinin padişah iradesi gereği olduğunu vurgulayarak, Serkurenâ Nevres Paşa'dan sonra ${ }^{56}$ bu hususa dikkat edilmediğini yaptığ kendisine verilmediğini yineler. Rusya Sefareti’nde hazırlandığı düşünülen masraf listesine resim malzeme masraflarını da ekledi. Hesap pusulasının birinde ${ }^{57}$ Chlebowski'nin, iki sene olan hizmet süresi üç sene olarak yazılmıştır. Bu zaman dilimi içinde, resim çalışmaları için aldığı boya, tasvir muşambası, firça, kıl kalem, tasvir revganı, kâğıt, kurşun kalem ve muhtelif levazımat masrafları için ortalama her ay 50 lira olmak üzere toplam 1.800 Osmanlı lirası hesap çıkardı. Mabeyn-i Hümâyûn'da çalıştığı dönem için 5 bin Osmanlı altını alacağı olduğunu, 24 Eylül 1872'den 24 Haziran 1875 tarihine kadar senelik yüzde on ikiden otuz üç aylık faizi olan 1.650 lira ile birlikte toplam 6.650 Osmanlı altınının kendisine ödenmesini talep etti.

$\mathrm{Bu}$ husustaki taleplerini saray ressamlığından ayrılmadan önce de ilettiği halde talebinin henüz yerine getirilmediğini, geçim sıkıntısı içinde olduğunu belirterek: "Bu hizmette bunca yıl kusursuz ve dürüst bir şekilde dikkat ve sadakatle çalışmaya gayret ettiğim, padişahın taltiflerine muhtaç olduğum halde, bir gûna mal mülk sahibi olamadım. Hâlihazırda borç içinde bulunduğumu padişaha arz ile söz konusu matlubatımın Mabeyn-i Hümayun'dan ödenmesi ve refahımın sağlanmasını talep etmekteyim” demektedir.

Saray için yapmış olduğu 23 adet resimden dolayı borcun ödenmesini talep eden ressamın hesapları ve masraf kayıtları incelendi (Temmuz 1875). İncelemeler neticesinde, resmi görevi "Mabeyn-i Hümâyûn Tasvirciliğii” olarak belirtilen Chlebowski’nin, saraydaki hizmeti süresince yaptığı resimler, malzeme masrafları, padişahın ihsanları ve iki sene boyunca aldığı maaşlarına dair iki masraf listesi hazırlandı.

İki sene boyunca yaptığı tasvirler karşılığında 559.800 kuruş; maaş olarak toplam 116.333 kuruş olmak üzere yekûn 676.133 kuruş ödeme yapıldığına dair hazırlanan hesap pusulalarından biri Hazine-i Hassa'ya gönderildi (4 Şubat 1874) ${ }^{58}$.

Yalnız, her ay 5 bin lira maaş alan ressama tahsis edilen maaşları gösteren iki ayrı listede farklılık dikkati çekmektedir. Maaş listesinin birinde, ressama iki sene boyunca ödenen

55 BOA, İ.HR, 268/16125.

56 Nevres Paşa, bu görevinden 2 Ağustos 1871 'de ayrılmıştır.

57 BOA, İ.HR, 268/16125.

58 BOA, MB, 156/100. 
toplam maaş 125.000 kuruş olarak kaydedilirken, diğer bir listede toplam 116.333 kuruştur. Burada ressama ödenen son maaş (24. maaşı) 1.333 lira olarak belirtilmiştir. Bu ise, ressamın son maaşı için 1.667 kuruş alacağı olduğunu düşündürmekte ise de bu hesaplamanın dikkate alınmadığı resmi yazışmalardan anlaşılmaktadır. Bununla birlikte, 13 Eylül 1872 tarihinde ressama verilen ve diğer listede kayıtlı 400 Osmanlı lirası da bu listede yer almamıştır.

Esas alınan masraf listesine göre; ressamın yaptığı resimler için ödenen meblağ ile padişahın ihsanları toplam olarak 441.800 kuruş tutmaktadır ${ }^{59}$. Ayrıca ressama verilen iki senelik maaş toplamı olan 125.000 kuruş buna dâhil edildiğinde, genel toplam 566.800 kuruştur.

\section{Atiyye-i Seniyye Verilmesi ve Hesap Meselesinin Kapanması}

Ressam Chlebowski, resim üretimi nedeniyle hak ettiği ücretten bir kısmının kendisine ödenmediği iddiasıyla Osmanlı hükümetine müracaatını müteakiben, Ceyb-i Hümâyûn Hazinesi kayıtlarının incelenmesiyle meselenin şu şekilde çözülmesine karar verildi (24 Temmuz 1875): “Ressam Hlebovski'nin Rikâb-ı Hümâyûn'a takdim edip tezkire-i samiye ile gönderilen arzuhal ve pusulalart incelenmiş; ressamın görevi sona erdiğinde hesabı da görüldüğ̈̈ sırada alacă̆ı olduğuna dair bir iddiada bulunmayıp bir süre sonra ressam hesap ve matlubum var diyerek alacak iddiasına girişmiştir. Rusya Sefareti tarafindan yapılan müracaat üzerine, Hazine-i Hassa ile muhabere yapılmış, ancak bu işe kesin bir hüküm verilememiştir. Borç talebi ve arzuhaline binaen padişahın merhametine uygun olur şekilde atiyye-i seniyye şeklinde bir miktar verilmesinin uygun olacağ kanaatine varılmıştır" ${ }_{00}$

Ressamın hak ettiği tüm meblağın ödendiği ve hiçbir alacağı kalmadığı kesinlik kazandığından, hizmeti döneminde, yaptığı masrafları ve maaşlarını tahsil ettiği halde sonradan alacağı olduğuna dair iddiasının ise anlamsız olduğu belirtilir. Hesap pusulasında, alacağı miktara ilave olarak "24 Eylül 1872-24 Haziran 1875 tarihleri arasında 33 aylık gecikme faizi (1.650 lira) konusu ise Osmanlı hükûmetince dikkate alınmaz.

Dolayısıyla ressamın esas matlupta hakkı olmadığı halde, talep ettiği 5 bin liraya mukabil kendisine 1.500 Osmanlı lirası atiyye-i seniyye verilmek suretiyle borç meselesinin “padişahın şanına yakışır şekilde halledilmesi” teklif edilir (18 Ağustos 1875).

Rusya Sefareti'nin de buna muvafakat ederek 1srarcı olmaması üzerine ressama, belirtilen meblağ "atiyye-i seniyye" kabilinden padişah iradesiyle Maliye Nezareti'nce ödenir (10 Eylül 1875). Bu arada, ressamın ileride alacak meselesi hususunda iddialarına mahal bırakılmayarak hesap işinin kapandığına dair bir tedbir olarak kendisinden alınan imzalı evrak Hazine-i Hassa'da muhafaza edilir.

59 BOA, MB, 145/132.

60 BOA, İ.HR, 268/16125. 
Söz konusu meblağın Chlebowski’yi tatmin etmediği anlaşılmaktadır. Osmanlı'nın ekonomik durumunun bozulması sebebiyle kendisine düşük miktarda ödeme yapıldığını düşünür ${ }^{61}$. Rusya Sefareti'nde baş dragoman Onou Bey’e yazdığı mektupta saray ile alacak hesabını kapattığını, bu meseleden üç yıl öncesinden vazgeçmediğine pişmanlık duyduğunu yazar. $\mathrm{Bu}$ hesap meselesinin kendisini çok uğraştırarak maddi ve manevi sıkıntıya düşürdügünü vurgular. Uzun süren uğraşlar neticesinde aldığı bu para ile sadece faturalarının borcunu kapatabildiğini ifade eder ${ }^{62}$.

\section{Ressamın Ülkesine Dönüşü}

Asıl ilginç nokta, bu süreçte Paris'e taşınmak üzere hazırlıklar yapan ressamın, Abdülaziz'in tahtan indirilmesi ve vefatı (4 Haziran 1876) sonrasında kesin olarak İstanbul'dan ayrılmasıdır. Bu süreçte ailesine yazdığı mektuplarda, padişahı ve dönemini eleştiren sözleri dikkati çekmektedir.

İstanbul'dan ayrılmasının akabinde önce Polonya'ya giden ressam, kısa bir süre sonra Fransa'ya geçerek Paris'e yerleşmeye karar verir. Burada atölyesini organize eder; içerisinde eski silahlar, kumaşlar, egzotik kaplar ve sair eşyaların bulunduğu adeta müze görünümündeki bu mekânda tarih konulu tablolarını yapmayı sürdürür, sergilere katılır ${ }^{63}$. 1877, 1878 ve 1879 tarihlerinde Paris salonlarında eserlerini sergiler. 1881'de ise Krakov'a yerleşen ressam ${ }^{64}$ muharebe konulu resimlerinin yanı sıra gündelik hayatı tasvir eden tablolar da yapar. 18 Eylül 1884 'te Poznanya şehrine yakın Kovanuvka köyünde ölen ressamın mezarı Polonya'dadır ${ }^{65}$.

61 Wójçik, "Stanislaw Chlebowski”, s. 51.

62 Roberts, İstanbul Karşılaşmalarl, s. 281.

63 www.stydiai.ru/21.12.2019.

64 Polonya Sanatında Oryantalizm, s. 332.

65 Donogo, Pobedit Tot, Kto Vladeet Kavkazom, s. 268. 


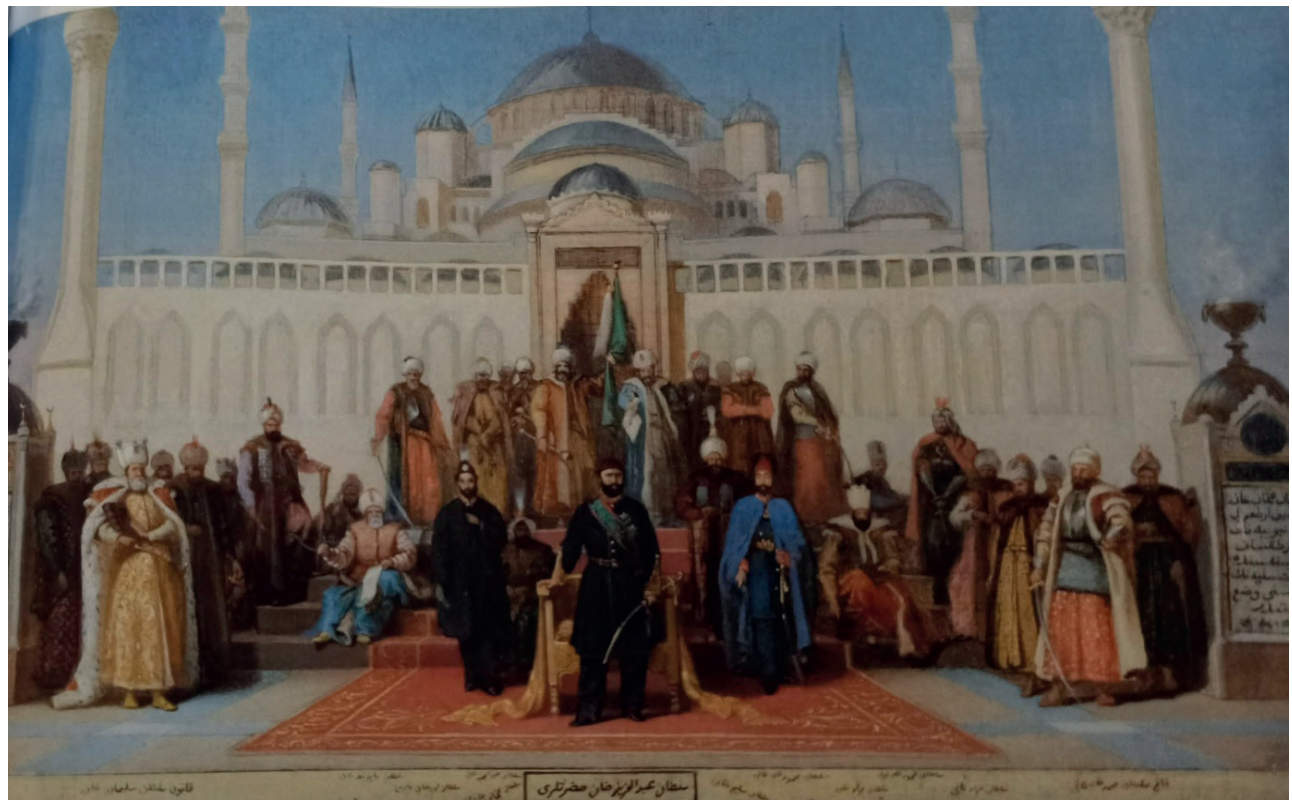

Resim 8

Stanislaw Chlebowski, “Türk Sultanları”, tuval üzerine yağlıboya, 23 x 38,8 cm. (Livov Resim Galerisi, Env. Nr. J-434).

\section{Chlebowski’nin İstanbul'da Yaptığı Tarihî Konulu Tablolardan Bazıları}

Devletin askerî gücü kadar diplomasinin de etkili olduğu bu dönemde sanatın etkileyici özelliğinden istifade etmek isteyen Sultan Abdülaziz, kronolojik bir tertiple Osmanlı klasik döneminin askerî zaferleri, fetihleri ve gurur verici muharebelerini konu alan tablolar yaptırır.

Ayrıca ressam, tam boy Sultan Abdülaziz'in portresini ve sultanların tasvirlerini de yapmıştır. Ressamın, Sultan Ahmed Camii avlusunda Osmanlı hanedanı üyeleriyle birlikte Abdülaziz'i tasvir eden “Türk Sultanları” (1867) adlı tablosu oldukça ilgi çekmektedir ${ }^{66}$.

66 Tuval üzerine yağlıboya 23x38,8 cm., Lvov Ulusal Sanat Galerisi, Env. Nr. J-434 (Galeriye 1913'te satın alınmıştır). 


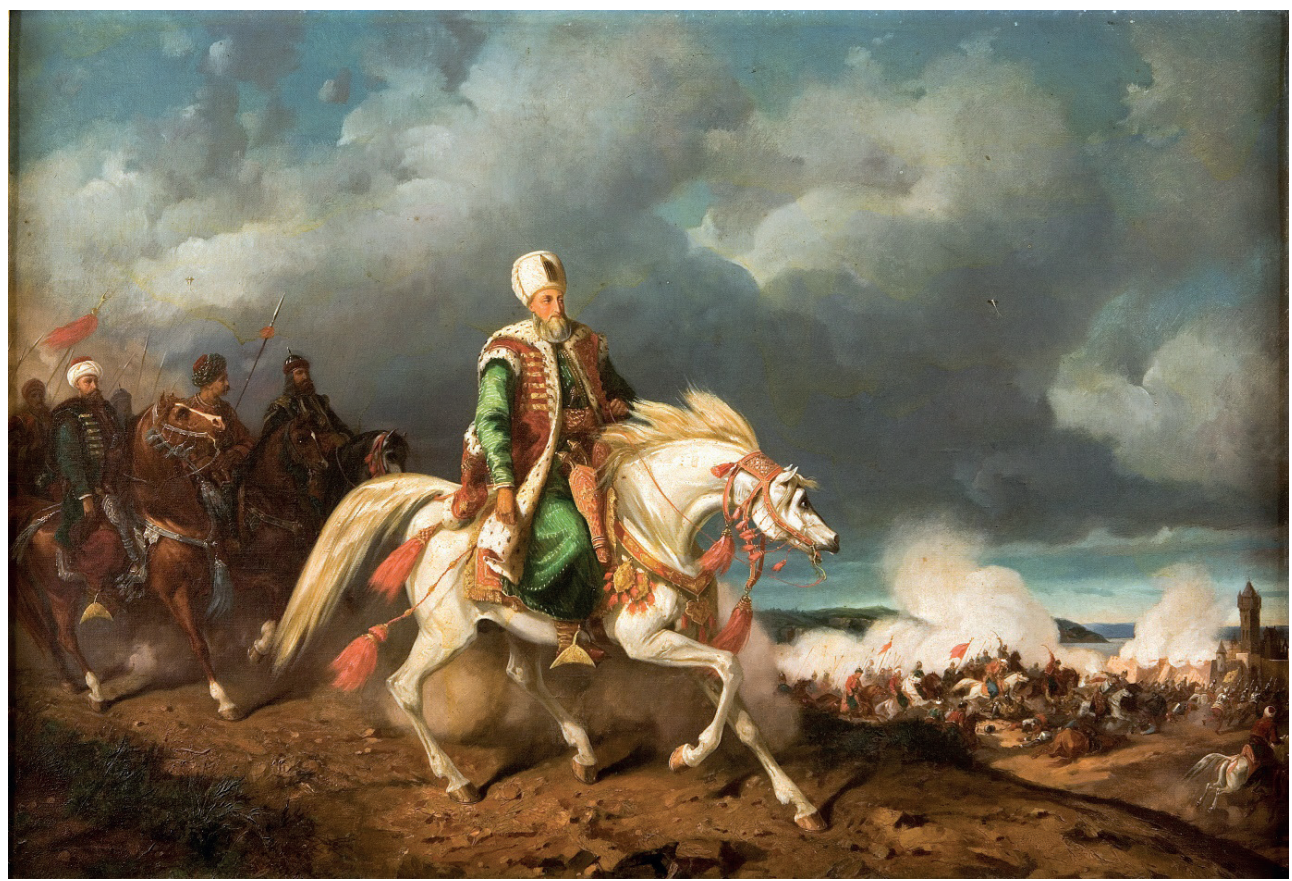

Resim 9

Stanislaw Chlebowski, “Kanuni Sultan Süleyman”, tuval üzerine yağlıboya, 62 x 92,2 cm. (Milli Saraylar Tablo Koleksiyonu, Env. Nr.11/1521).

Chlebowski'nin Osmanlı sarayındaki hizmeti süresince (1870-1872) 1 adet büyük boy, 18 adet orta ve küçük boy muharebe resimleri, Nuri Bey yardımıyla tasvir ettiği 3 adet bahriye resimleri, padişahlardan Sultan Abdülaziz, Sultan I. Selim, Sultan II. Selim'in portreleri, Sultan Abdülaziz'in kızı Saliha Sultan'ın portresi yanında Kâğıthane ve Göksu resimleri ile birkaç adet Çiftlik resimi yaptığg arşiv kayıtlarından anlaşılmaktadır. 


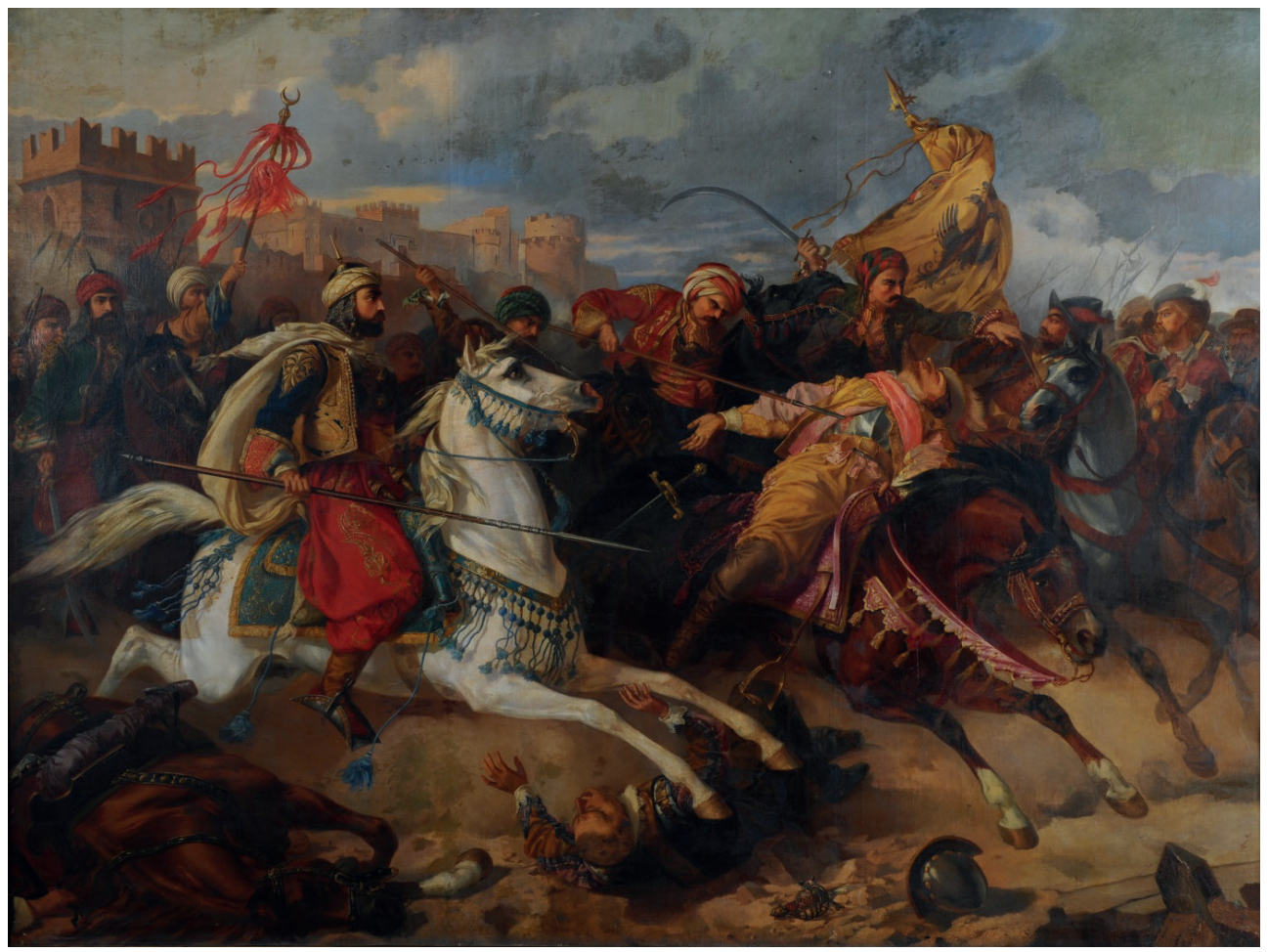

Resim 10

Stanislaw Chlebowski, "Varna Meydan Muharebesi”, tuval üzerine yağlı boya, 287 x $394 \mathrm{~cm}$. Resmin sağ alt köşesinde Osmanlı harfleri ile "Ressam Hleboski", Latin harfleri ile "Chlebowski 1865” imza ve tarihi vardır (Askeri Müze Resim Koleksiyonu, Env. Nr. 504). 


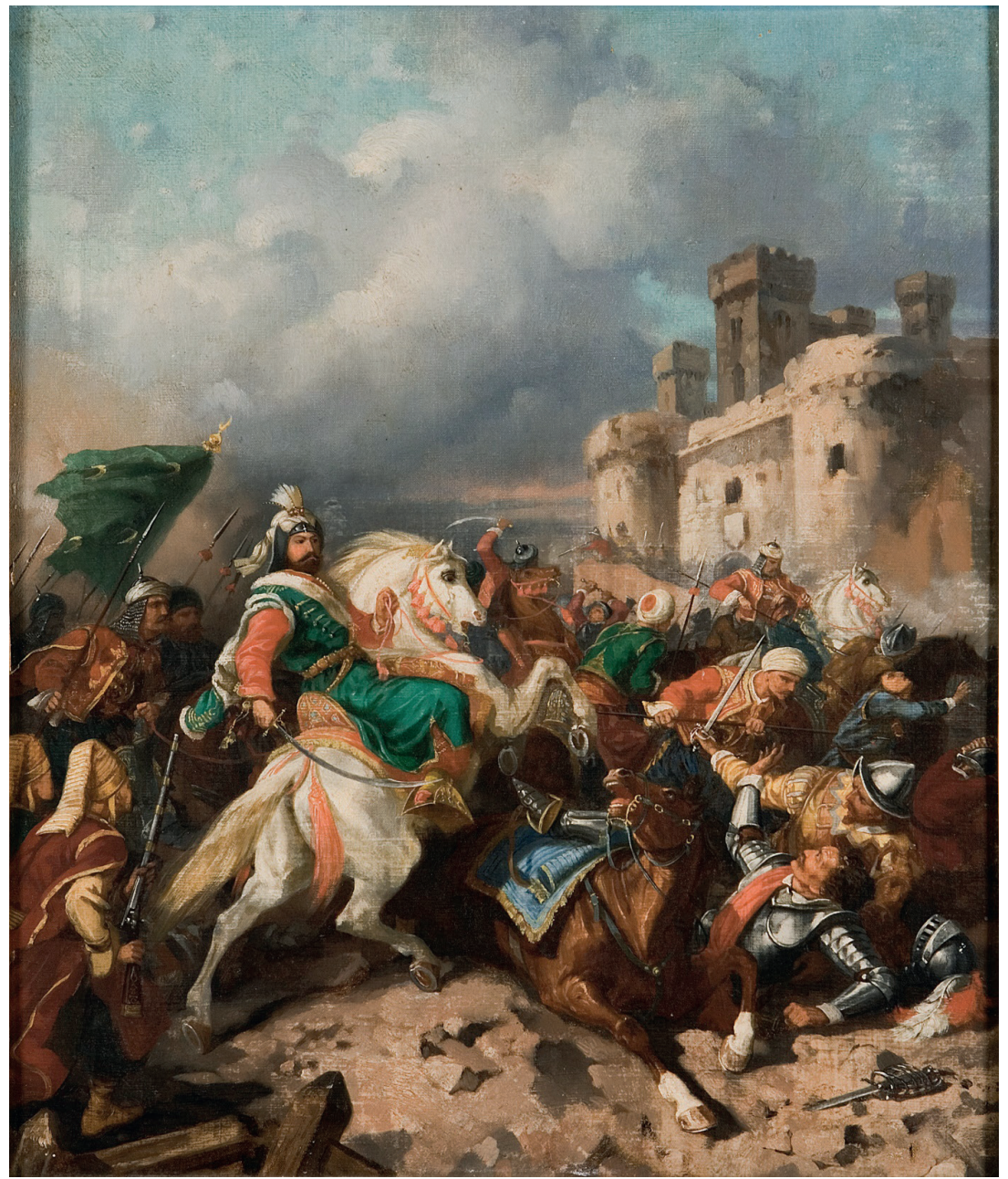

Resim 11

Stanislaw Chlebowski, “Sultan IV.Murad'ın Bă̆dat Seferi”, tuval üzerine yağlıboya, 38,5 x 46,5 cm. (Milli Saraylar Tablo Koleksiyonu, Env. Nr. 11/1499).

Mabeyn-i Hümayûn kayıtlarına göre ressamın yaptığı resimler tarihleriyle şöyle siralanabilir ${ }^{67}$ :

1 adet büyük boy muharebe resmi (Haziran 1870), 1 adet küçük boy muharebe resmi (Temmuz 1870), 1 adet büyük boy muharebe resmi (Temmuz 1870), 2 adet küçük boy muharebe resmi (Eylül 1870), 1 adet küçük boy Rum Muharebesi resmi (Ekim 1870), 1 adet küçük boy Orta Nemçe Muharebesi resmi (Ekim 1870), 1 adet küçük boy muharebe resmi

67 BOA, İ.HR, 268/16125; MB, 145/132; 156/100. 
(Kasım 1870), 1 adet orta boy muharebe resmi (Aralık 1870), 1 adet Sultan I. Selim Portresi (Aralık 1870), 1 adet Sultan II. Selim Portresi (Aralık 1870), 1 adet Saliha Sultan Portresi (Aralık 1870), 1 adet Edirne Muharebesi resmi (Şubat 1871), Kâğ thane resmi (Eylül 1871), Göksu resmi (Eylül 1871), birkaç adet Çiftlik resmi (Aralık 1871), Mohaç Muharebesi (Şubat 1872), Tasvir-i Hümayun (Padişah tarafından Sadrazam Mahmud Nedim Paşa'ya ${ }^{68}$ hediye edilen fildişi üzerine Sultan Abdülaziz'in minyatür portresi, Şubat 1872), 1 adet konusu belirtilmeyen resim (Mart 1872), Nuri Bey yardımıyla tasvir ettiği bahriye resimleri (3 adet).

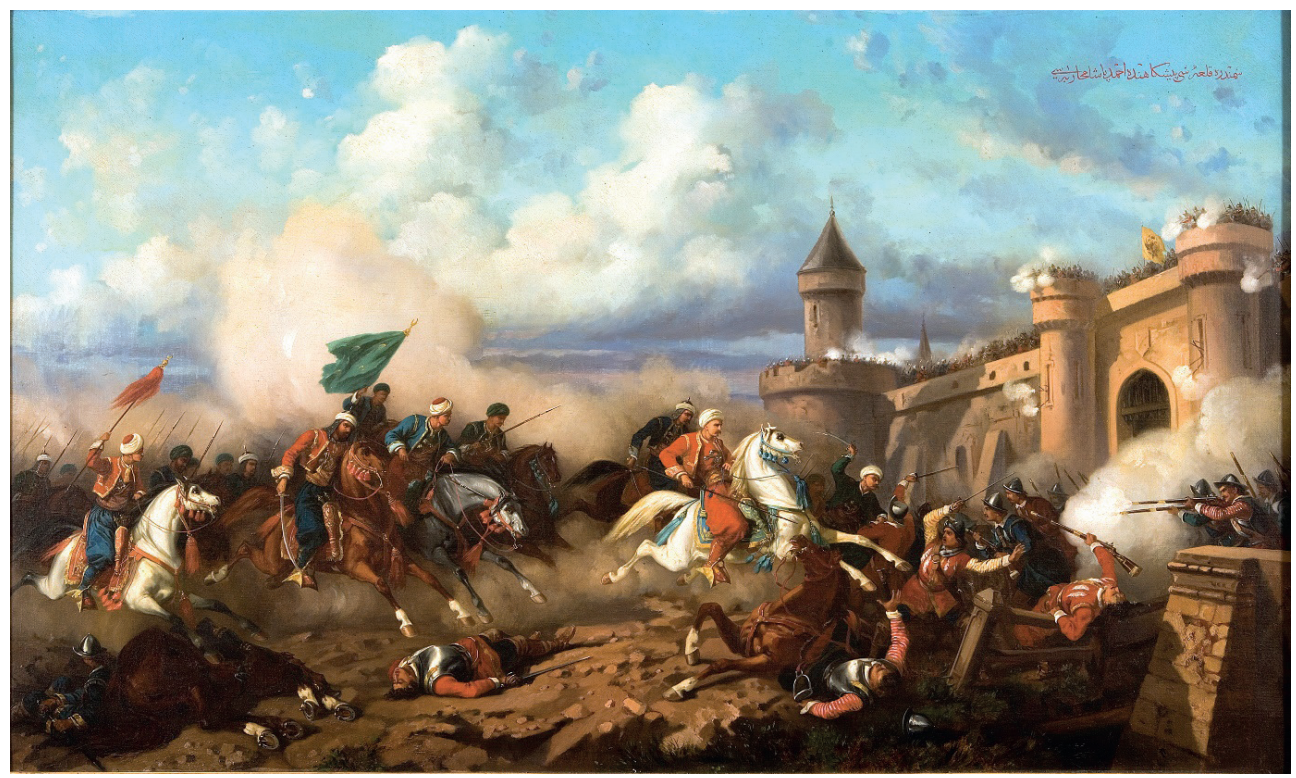

Resim 12

Stanislaw Chlebowski, "Semendire Kalesi'nin Kuşatılması", tuval üzerine yağlıboya, 75,6 x 124,6 cm. Resmin sağ üst köşesinde, "Semendire Kalesi Pişgâhında Ahmed Paşa Muharebesi” yazılıdır (Milli Saraylar Tablo Koleksiyonu, Env. Nr.11/1491).

68 Sadrazam Âli Paşa'nın vefatı üzerine bu göreve tayin edilen Mahmud Nedim Paşa’nın birinci sadrazamlık dönemi 8 Eylül 1871-31 Temmuz 1872, ikinci sadrazamlık dönemi ise 26 Ağustos 1875-11 Mayıs 1876 tarihleri arasındadır. 


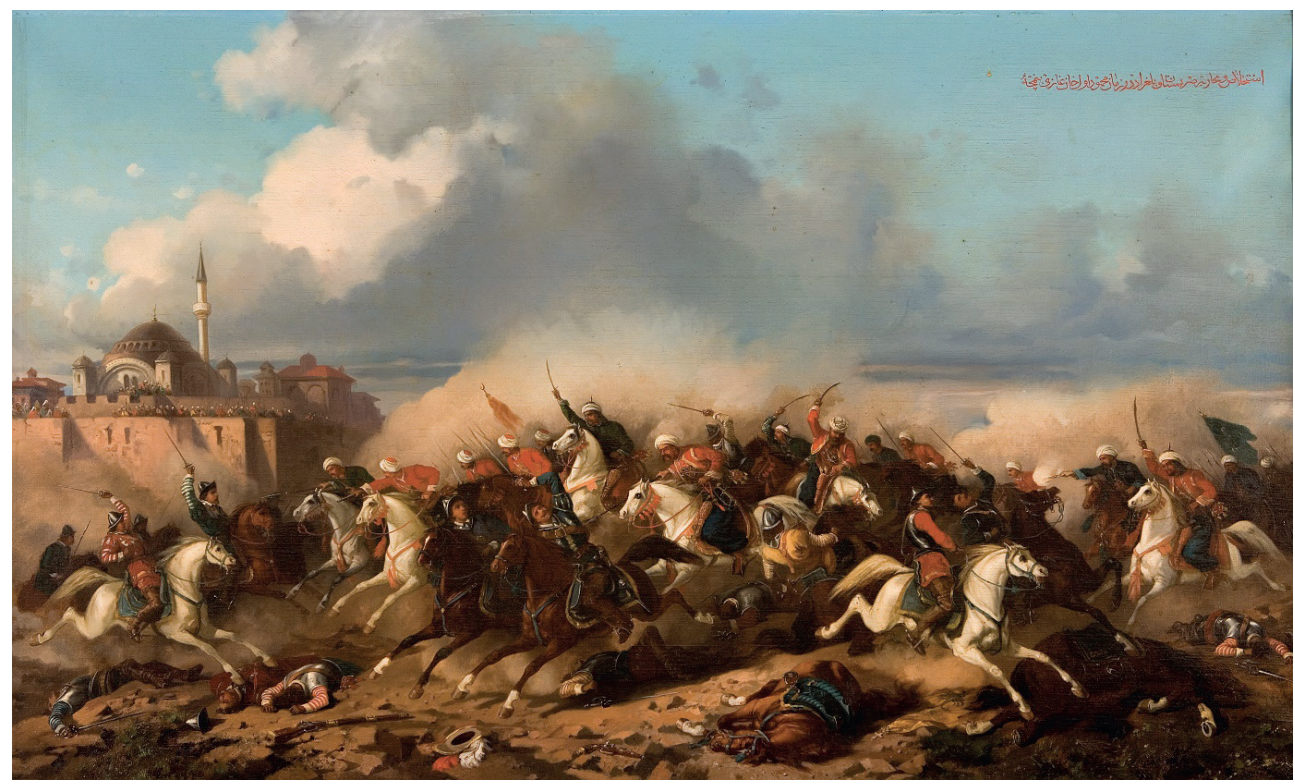

\section{Resim 13}

Stanislaw Chlebowski, "Sultan I. Mahmud Devrin'de Belgrad Kalesi'ne Hücum”, tuval üzerine yağlıboya, 75 x 124,3 cm. Resmin sağ üst köşesinde, "İ̀stihlâs ve muharebe-i Sırbistan ve Belgrad der-zeman-ı Mahmud-ı Evvel Han-ı Gazi benemçetü” yazılıdır (Milli Saraylar Tablo Koleksiyonu, Env. Nr. 11/1496).

Saray ressamlığından ayrıldıktan sonra Osmanlı tarihinden tarihî kesitleri yansıtan farklı tasvirler de yapmıştır. Chlebowski’nin, Livov Resim Galerisi’nde bulunan yirmiye yakın eseri içerisinde savaş sahneleri, İstanbul'un farklı mekânlarını yansıtan resimler yanında portreler de vardır. "Esaretteki Sultan”, “Timur'un Esaretindeki Sultan Bayezid” (1878) "İstanbul'da Bir Sokak” (adlı bu resmin sağ alt köşesi “1875, St. Ch” imzalı) 70; “Varnençik'in Ölümü”" ("St. Ch" imzalı) ${ }^{72}$ konulu tablolar bunlardan bazılarıdır.

69 Shid u Tvorçesti Evropeyskih Hudojnikiv Albom Katalog, Lviv 2008, s. 35.

$7034 x 28.8$ cm. Livov Resim Galerisi, Env. Nr. J-257, (1913’te galeriye satın alınmıştır).

$7138 \times 47 \mathrm{~cm}$. Varna Muharebesi’nde (1444) Kral III. Varnençik'in ölümünün tasvir edildiği düşünülmektedir.

72 Livov Resim Galerisi, Env. Nr. J-246. 


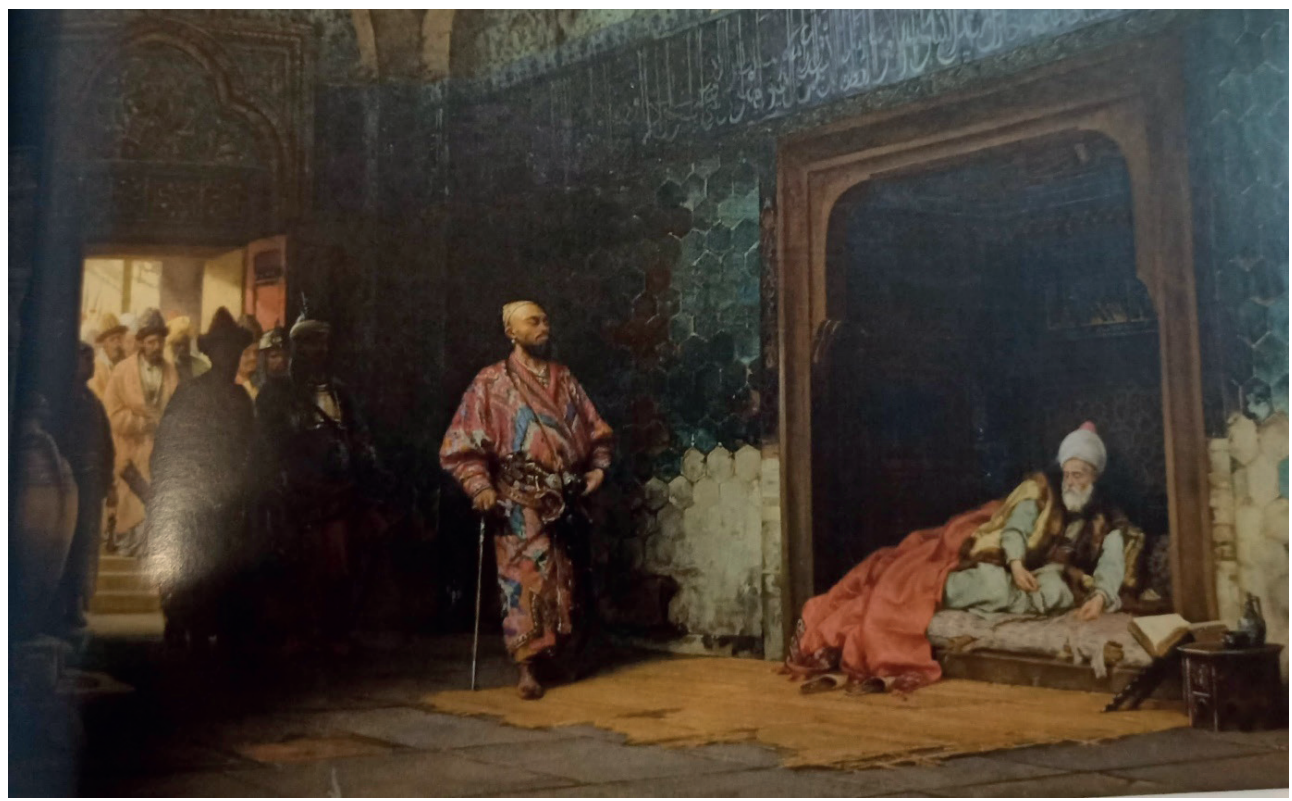

Resim 14

Stanislaw Chlebowski, “Timur'un Esaretindeki Sultan Bayezid” 1878, 27,3 x 40 cm. Resmin sol alt köşesinde "St. Chlebowski 1878" imza ve tarihi vardır (Livov Resim Galerisi, Env. Nr. J-437).

Ressamın eserleri günümüzde sadece Türkiye'de değil, Polonya, Fransa ve Ukrayna'daki müzelerde sergilenmektedir. Milli Saraylar Tablo Koleksiyonu'nda Stanislaw Chlebowski’ye ait olduğu düşünülen on altı adet tablo bulunmaktadır. Bu eserlerden biri günlük hayattan bir kesit, diğerleri Türk tarihiyle ilgili çok figürlü kompozisyonlardır ${ }^{73}$. Ressamın tablolarından bazıları ise Harbiye'deki Askeri Müze Resim Koleksiyonu’ndadır74.

Sonuç olarak, Osmanlı sarayında yüksek maaşla istihdam edilen Avrupalı ressamlar, öncelikle kendilerine verilen siparişleri yerine getirmek ve talepler istikametinde eserler üretmek mecburiyetinde olan ressamların bu noktada serbest resim yapmaktan ziyade, talep ve siparişlerin tasvirlere yön verdiği açıktır. Sultan Abdülaziz zamanında, sarayda çalışmak hususunda istekli olan birçok Avrupalı ressamın arasından, Leh asıllı Rus tebaası Stanislaw Chlebowski tercih edilerek sarayda istihdam edilmiştir. Bu tercihte, 1864 yılı sonlarından itibaren İstanbul'da bulunan ressamın saray için resimler yaparak kendisini tanıtması yanında, bu görevi talep ederek bazı girişimlerde bulunmasının da etkili olduğu muhtemeldir.

73 Gülsen Sevinç Kaya, "Sultan Abdülaziz ve Döneminin Resim Sanatı", Milli Saraylar Sanat-Tarih-Mimarlık Dergisi/National Palaces Journal of Art-History-Architecture, say1 17 (2019), s. 94; Gülsen Sevinç Kaya, Milli Saraylar Tablo Koleksiyonu, Milli Saraylar, İstanbul 2019, s. 302-317.

74 Askeri Müze Resim Koleksiyonu Kataloğu, İstanbul 2011. 
Sultan Abdülaziz tarafından "Mâbeyn-i Hümâyûn Ressâmı" olarak tayin edilen Chlebowski'nin, Saraydaki hizmeti süresince yaptığı büyük, orta ve küçük boyda genel olarak Osmanlı klasik döneminin askerî zaferleri, fetihleri ve gurur verici muharebelerini konu alan tabloları bilhassa dikkati çekmektedir. Sarayda yoğun çalışma temposu içinde bulunması, padişahın eserlerine sıç̧a müdahale etmesi, akşamları bile saraya çağrılarak resimlerde düzeltmeler yapmak zorunda kalması ressamı bunaltmıştır. Buna saray ortamındaki ilişkilerinde huzursuzluk ve tedirginlik yaşaması eklenince ayrılmak zorunda kalmıştır. Öte yandan, yaptığı resimler karşılığında saraydan kendisine ödemelerin yapılmadığı, mağdur edildiği, fazla kazanç elde edemediği, tasavvur ettiği maddi birikimi yapamadığı iddiaları gerçeği yansıtmamaktadır.

Saraydan "hesap ve matlubum var" diyerek alacak iddiasında bulunan ressamın, bu iddialarında haksız olduğu, çalışmaları karşılığında yüksek maaş ve ihsanlar aldığı hesap kayıtlarından anlaşılmıştır. Hazırladığı eserleri ile daima padişahın takdir ve ihsanına mazhar olduğu, o dönemde sarayda çalışan diğer yerli ressamlardan fazla ücret ve ihsan almıştır.

İki sene saray ressamlığ hizmetinde bulunan ve yaklaşık on iki sene İstanbul'da kalan Chlebowski eserleri ve saraydaki statüsü ile uluslararası üne kavuşmuştur. Ne yazık ki, İstanbul'dan huzur içinde ve memnun olarak ayrılmayan ressamın saray yönetimine olan tepkileri sürmüştür. Öte yandan, Abdülaziz'in vefatının hemen sonrasında İstanbul'dan temelli ayrılan ressam, sanat faaliyetleri süresince "Abdülaziz'in Ressamı" ya da "Saray Ressamı" unvanını kullanma ya da gündeme getirme gibi bir tavır içinde bulunmamıştır.

İstanbul'da bulunduğu dönemde yaptığı klasik dönem Osmanlı fetihleri, muharebe konulu tabloları, portreler ile başkent İstanbul'un farklı mekânlarının hatıralarını yansıtan tarihî görsel mirası, günümüzde Milli Saraylar Müzesi ve Askeri Müze'de sergilenmektedir. Fakat Chlebowski'nin saray ressamlığı döneminde yaptığı bahriye resimlerinin konuları ve bulundukları yerlerin tespiti yeni araştırmaları beklemektedir.

\footnotetext{
Hakem Değerlendirmesi: Dış bağımsız.

Çıkar Çatışması: Yazar çıkar çatışması bildirmemiştir.

Finansal Destek: Yazar bu çalışma için finansal destek almadığını beyan etmiştir.
}

Peer-review: Externally peer-reviewed.

Conflict of Interest: The author has no conflict of interest to declare.

Grant Support: The author declared that this study has received no financial support. 


\section{Kaynakça/References}

\section{Arşiv Kaynakları}

Türkiye Cumhuriyeti Cumhurbaşkanlığı Devlet Arşivleri Başkanlığı Osmanlı Arşivi (BOA)

Bâb-1 âli Evrak Odası, Nezaret Devair Gelen-Giden Defterler (BEO, NDGGD.), Maarif Giden, nr. 58/100, 395/9-6.

Hazine-i Hassa Tasnifi İrade (HH.İ.).

Hariciye Nezareti Tahrirat Odası (HR.TO.).

İrade Tasnifi

Dahiliye (İ.DAH.).

Hariciye (İ. HR.).

Mabeyn-i Hümayun Evrakı (MB.).

İrade (MB.İ.).

Topkapı Sarayı Müzesi Arşivi Defterleri (TSMAD.) 00348.0001.00. 001; 00379.0001.003; 00401.0004.003; 00402.0004.00.002; 00402.012.002.

\section{Yayınlanmış Eserler}

Askeri Müze Resim Koleksiyonu Kataloğu, İstanbul 2011.

Budak, Mustafa, "Şeyh Şâmil”, DİA, XXXIX, 2010, s. 67-70.

Donogo, Hadji Murad, Pobedit Tot, Kto Vladeet Kavkazom, Miniaturı Kavkazkoy Voynı 1817-1864, Moskova 2015.

Göncü, T. Cengiz, "Osmanlı Sarayında Resim Sanatının Himayesinin Simgesi Olarak Resim Odası ve Görev Alan Sanatçılar”, Milli Saraylar Sanat-Tarih-Mimarlık Dergisi, say1 9, İstanbul 2012, s. 263-277.

Halil Edhem [Eldem], Elvâh-ı Nakşiye Koleksiyonu, İstanbul 1340.

Histoire de la Guerre D’orient İllustré par Janet-Lange, Éditeur, Gustava Barba, Paris 1854.

Jivopis XVIII-Naçala XX Veka (Do 1917 Goda), Moskova 1952.

Kaya, Gülsen Sevinç, "Sultan Abdülaziz ve Döneminin Resim Sanatı”, Milli Saraylar Sanat-Tarih-Mimarlık Dergisi/National Palaces Journal of Art-History-Architecture, say1 17 (2019), s. 77-101. , Milli Saraylar Tablo Koleksiyonu, Milli Saraylar, İstanbul 2019.

Küçük, Cevdet, “Abdülaziz”, DİA, I, 1988, s. 179-185.

Kondakov, Sergey Nikodimoviç, Yubileynıy Spravoçnik Imperatorskoy Akademii Hudojestv 1764-1914, Tom II, St. Petersburg 1915.

Konovalov, Eduard Gavriloviç, Slovar Russkih Hudojnikov: Novıy Polnıy Biografiçeskiy, Moskova 2008.

Köprülü, Orhan F., "Fuad Paşa, Keçecizâde (1815-1869)”, DİA, XIII, 1996, s. 202-205.

Polonya Sanatında Oryantalizm, Pera Müzesi Yayınları, İstanbul 2014.

Roberts, Mary, İstanbul Karşılaşmaları, Osmanlılar, Oryantalistler ve 19. Yüzyıl Görsel Kültürü, çev. Zeynep Rona, İş Bankası Kültür Yayınları, İstanbul 2016.

Shid u Tvorçesti Evropeyskih Hudojnikiv Albom Katalog, Lviv 2008. 
Solovyev, Vladimir Daniloviç, "Hlebovskiy Stanislav (1835-1884)", Ruskie Hudojniki XVIII-XX Vekov: Spravoçnik, Moskova 2005.

Ürekli, Fatma, "Arşiv Belgeleri Işı̆̆ıında Osmanlı Sarayında Nişanlarla Takdir ve Taltif Edilen Ressam Ayvazovski'nin Bilinmeyenleri”, Milli Saraylar Sanat-Tarih-Mimarlık Dergisi/National Palaces Journal of Art-History-Architecture, say1 17 (2019), s. 7-31.

, Sarayın Son Başressamı Fausto Zonaro İkbâlden İdbâra, Türkiye İş Bankası Kültür Yayınları, İstanbul 2017.

Wójçik, Agata, "Stanislaw Chlebowski, Sultan Abdülaziz’in Sarayında”, çev. Nazan Erbil, Milli Saraylar Sanat-Tarih-Mimarlık Dergisi/ National Palaces Journal of Art-History-Architecture, say1 17 (2019), s. 33-51.

\section{Süreli Yayınlar}

Istikbal.

La Turquie.

Le Monde Illustré Journal.

L'Illustration Journal Universal.

Osmanli Ressamlar Cemiyeti Gazetesi.

Ruzname-i Ceride-i Havadis.

Takvim-i Vekayi.

\section{Internet Kaynakları}

www.stydiai.ru/21.12.2019. 


\section{EKLER}

\section{Ek 1}

Resim Oda-yı Âlîsi’nde Çalışan Ressamlar İçin 18 Eylül 1870-22 Şubat 1873 Tarihleri Arasında Satın Alınan Malzemeler ve Masrafları

(BOA, MB, 156/100).

\begin{tabular}{|c|c|c|}
\hline \multicolumn{2}{|c|}{ Ressamlar için alınan eşya esmânıyla mesârıfları olarak verilen meblağ } & \multirow{2}{*}{\begin{tabular}{|l|} 
Guruş \\
300 \\
\end{tabular}} \\
\hline \multirow{10}{*}{$\begin{array}{l}\text { Nevres Paşa } \\
\text { Zamanında Alınan } \\
\text { Eşya Esmânı }\end{array}$} & Resim kâğıdı bahâsı olarak Müdür Mustafa Efendi’ye, 6 Eylül 1286 & \\
\hline & Resim kâğıdı bahâsı olarak Müdür Mustafa Efendi’ye, 7 Eylül 1286 & 550 \\
\hline & Yedi adet yaldızlı resim çerçevesi bahâsı olarak Aleko’ya & 7.900 \\
\hline & Resim kâğıdı bahâsı olarak, 14 Kânun-1 Evvel 1286 & 210 \\
\hline & Yaldızlı resim çerçevesi bahâsı olarak Aleko'ya, 14 Kânun-1 Sâni 1286 & 12.300 \\
\hline & Resim kâğıdı bahası, Şubat 1286 & 720 \\
\hline & \begin{tabular}{|l|l} 
Ressam Nuri Bey marifetiyle alınan çerçeve ve saire bahâsı, 25 Mart 1287 \\
\end{tabular} & 3.683 \\
\hline & Resim çerçevesi ve saire bahâsı olarak Aleko'ya, Nisan 1287 & 7.800 \\
\hline & Resim kâğıdı bahâsı olarak Mustafa Efendi’ye, 6 Haziran 1287 & 200 \\
\hline & Toplam & 33.663 \\
\hline \multirow{9}{*}{$\begin{array}{l}\text { Hurşid Bey } \\
\text { Zamanında Alınan } \\
\text { Eşya Esmânı }\end{array}$} & Resim bahâs1 olarak Müdür Mustafa Efendi’ye, Nisan 1287 & 178 \\
\hline & Resim çerçevesi bahâsı olarak Aleko’ya, Mayıs 1287 & 3.250 \\
\hline & Resim bahâsı olarak Müdür Mustafa Efendi’ye, Mayıs 1287 & 825 \\
\hline & Resim çerçevesi bahâsı olarak Aleko’ya, Haziran 1287 & 4.200 \\
\hline & Resim çerçevesi bahâsı olarak Aleko’ya, Haziran 1287 & 3.200 \\
\hline & Ressam Nuri Bey'in masârıfı, Temmuz 1287 & 680 \\
\hline & Ressam Nuri Bey'in boya vesaire bahâs1, Temmuz 1287 & 452 \\
\hline & Ressam için yaldızlı çerçeve bahâsı olarak Aleko'ya, 24 Şubat 1287 & 5.500 \\
\hline & Toplam & 18.285 \\
\hline $\begin{array}{l}\text { Fuad Bey } \\
\text { Zamanında Alınan }\end{array}$ & $\begin{array}{l}\text { Bir adet kebîr ve bir adet sagîr yaldılılı resim çerçevesi esmanı olarak } \\
\text { Aleko'ya verilen, } 11 \text { Şubat } 1285\end{array}$ & 4.500 \\
\hline \multirow{8}{*}{$\begin{array}{l}\text { Ziver Bey } \\
\text { Zamanında Alınan } \\
\text { Eşya Esmanı }\end{array}$} & Aleko mârifetiyle alınan resim çerçevesi ve saire bahâsı, 21 Eylül 1287 & 4.896 \\
\hline & Resim çerçevesi ve saire bahası olarak Aleko’ya, 29 Eylül 1287 & 2.387 \\
\hline & Resim için Müdür Mustafa Efendi’ye verilen, Teşrin-i Sâni 1287 & 435 \\
\hline & Resim çerçeveleri esmanı olarak Aleko’ya, Kânun-1 Evvel 1287 & 5.892 \\
\hline & Ressam için alınan bazı eşya bahasına verilen, Kânun-1 Sâni 1287 & 385 \\
\hline & Ressamlar için alınan eşya esmânı olarak Aleko'ya, Kânun-1 Sâni 1287 & 2.600 \\
\hline & $\begin{array}{l}\text { Ressamlar için alınan eşya esmânı olarak Müdür Mustafa Efendi’ye Kânun-1 } \\
\text { Sâni } 1287\end{array}$ & 1.360 \\
\hline & Toplam & 17.955 \\
\hline $\begin{array}{l}\text { İzzet Bey } \\
\text { Zamanında Alınan }\end{array}$ & Üç adet resim çerçevesi bahâsı olarak Aleko’ya, Ağustos 1288 & 4.700 \\
\hline $\begin{array}{l}\text { Mehmed Bey } \\
\text { Zamanında Alınan } \\
\end{array}$ & İki adet resim çerçeve bahâsı olarak, Ağustos 1288 & 3.200 \\
\hline \multirow{9}{*}{$\begin{array}{l}\text { Ziver Bey'in İkinci } \\
\text { Defa Serkurenalığı } \\
\text { Zamanında Alınan } \\
\text { Eşya Esmânı }\end{array}$} & Resim çerçevesi bahâsı olarak Aleko'ya, Teşrîn-i Evvel 1288 & 1.400 \\
\hline & Resim çerçevesi bahâsı olarak Aleko’ya, 13 Teşrîn-i Evvel 1288 & 2.185 \\
\hline & Resim çerçevesi bahâsı olarak Aleko’ya, 25 Teşrin-i Evvel 1288 & 1.500 \\
\hline & $\begin{array}{l}\text { Resim çerçevesi bahası olarak Müdür Mustafa Efendi’ye, } 29 \text { Teşrîn-i Sâni } \\
1288\end{array}$ & 2.645 \\
\hline & \begin{tabular}{|l|} 
Ressam Nuri Bey'in masârıfı, 30 Kânun-1 Evvel 1288 \\
\end{tabular} & 3.200 \\
\hline & Resim kitabı bahâsı olarak Müdür Mustafa Efendi’ye, 8 Şubat 1288 & 1.925 \\
\hline & 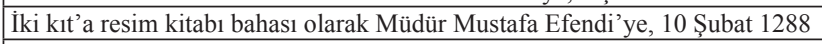 & 1.650 \\
\hline & Toplam & 14.505 \\
\hline & $\begin{array}{l}\text { YEKÛN GURUŞ } \\
\text { Ressam Nuri Bey’in aldığı eşya bahâsı olup tenzil olunan=4.332 kuruş }\end{array}$ & $\begin{array}{l}96.808 \\
96.808-4.332= \\
92.476\end{array}$ \\
\hline
\end{tabular}


Ek 2

Ressam Chlebowski’nin Takdim Ettiği, Saray Ressamlığı Döneminde Yaptığı Tasvirler ile Resim Malzemeleri Masrafları

(BOA, İ.HR, 268/16125).

Mabeyn-i Hümâyûn-1 Cenab-1 Mülûkane lâzimesi içün Ressam Hlebovski mârifet-i âcizânesi ile tasnî’ ve tasnif kılınan tesâvir ile celb ve tedârik olunan levâzımât-1 sanâyi fiyatlarını mübeyyin pusuladır.

\begin{tabular}{|l|l|l|}
\hline \multicolumn{1}{|c|}{ Aded } & \multicolumn{1}{|c|}{ Cinsi } & Lira-yı Osmânî Aded \\
\hline 1 & Tasvir-i kebîr & 400 \\
\hline & $\begin{array}{l}\text { Hengâm-1 memûriyet-i âcizîde mârifet-i çakeriyle celb ve tedârik olunan } \\
\text { boya ve tasvir muşamması ve firça ve kıl kalemi ve tasvir revgânı ve kağıd ve } \\
\text { kurşun kalem ve matbu resimler ve resim kitapları ve örneklik numuneler ve } \\
\text { icrâ-yı hiref-i sanâyî içün levâzımat-1 cüzîyye-i saire üç sene zarfında beher- } \\
\text { mâh ellişer liradan }\end{array}$ & 1.800 \\
\hline 8 & Atufetlü Ziver Bey zamanında vasat tasvir, beheri 150 kuruş & 1.200 \\
\hline 7 & Atufetlü Hurşid Bey zamanında keza vasat tasvir, beheri 150 kuruş & 1.050 \\
\hline 1 & $\begin{array}{l}\text { Taraf-1 hazret-i şâhâneden sadr-1 esbak devletlü Mahmud Nedim Paşa } \\
\text { hazretlerine ihdâ buyurulan fildişi üzerine menkûş tasvir-i müsaffere }\end{array}$ & 200 \\
\hline 3 & Muahharan tasni ve tasnif olunan vasat tasvir, beheri 150 kuruş & 450 \\
\hline 3 & Nuri Bey muâveneti ile nakş olunan bahriye resmi, beheri 100 kuruş & 300 \\
\hline & Geçen Eylül'de alel-hesab teslim buyurulan & $400^{75}$ \\
\hline 23 & & $\begin{array}{l}5.400-400=5.000 \\
\text { Bakiyye-i matlûb } \\
\text { yalnız beş bin liradır }\end{array}$ \\
\hline
\end{tabular}

75 Eylül 1872 tarihinde ressama 400 kuruş ödeme yapılmıştır. 
Ek 3

Ressam Chlebowski’nin Takdim Ettiği, Saray Ressamlığı Döneminde Yaptığı Tasvirler ile Resim Malzemeleri Masrafları

(BOA, İ.HR, 268/16125).

\begin{tabular}{|c|c|c|}
\hline $\begin{array}{l}\text { Mabeyn-i Hün } \\
\text { mârifetiyle Ma } \\
\text { celb ve tedârik }\end{array}$ & $\begin{array}{l}\text { ûn cânib-i âlîsinde mukaddema tasvircilik hizmetinde müstahdem R } \\
\text { nn-i Hümâyûn lâzimesi içün tasni' ve tasnif olunan tesâvirin tadâdı b } \\
\text { niş olan levâzımât-1 sınâiye ve eşyâ-yı sairenin keyfîyet (ve) kemiyy }\end{array}$ & $\begin{array}{l}\text { essam Hlebovski bendeleri } \\
\text { eyânıyla icrâ-yı hiref içün } \\
\text { etini mübeyyin pusuladır. }\end{array}$ \\
\hline Aded/Guruş & Cinsi & $\begin{array}{l}\text { Yüzlük Osmanlı altını } \\
\text { (Aded) }\end{array}$ \\
\hline 1 & Tasvir-i kebîr & 400 \\
\hline & $\begin{array}{l}\text { Üç sene zarfında vasıta-i âcizânem inzimâmıyla celb ve tedârik } \\
\text { olunan boya ve tasvir muşamması ve firça ve kıl kalem ve tasvir } \\
\text { revgânı ve kağıd ve kurşun kalem ve icrâ-yı hiref ve sanâyi içün } \\
\text { levâzımât-ı cüzîyye-i sâire bâ-hesâb mutavassıt-ı beher mâh elli } \\
\text { aded yüzlük Osmanlı altını olarak }\end{array}$ & 1.800 \\
\hline 8/150 guruş & $\begin{array}{l}\text { Atufetlü Ziver Beyefendi’nin ser-kurenalığı hengâmında tasni’ ve } \\
\text { tasnif kılınan vasat tasvîr }\end{array}$ & 1.200 \\
\hline $7 / 150$ guruş & $\begin{array}{l}\text { Atufetlü Hurşid Beyefendi'nin ser-kurenalığı hengâmında tasni’ ve } \\
\text { tasnif kılınan vasat tasvîr }\end{array}$ & 1.050 \\
\hline 1 & $\begin{array}{l}\text { Sadr-1 esbak devletlü Mahmud Nedim Paşa Hazretlerine ihdâ } \\
\text { buyurulmak üzere fildişi üzerine musaffiren tasni' kılınan tasvir-i } \\
\text { âlî-i hazret-i şehriyârî }\end{array}$ & 200 \\
\hline $3 / 150$ guruş & Muahharan tasni' ve tasnif kılınan vasat tasvîr & 450 \\
\hline 3/100 guruş & $\begin{array}{l}\text { Nuri Beyefendi refâkati inzimâmile tasnî’ ve tasnif kılınan bahriye } \\
\text { tesâvîri }\end{array}$ & 300 \\
\hline & & 5.400 \\
\hline & $\begin{array}{l}\text { Eylül } 1288 \text { tarihinde ale'l-hesâb teslim kılınan yekûn asıl mâl-1 } \\
\text { matlûb }\end{array}$ & 400 \\
\hline & & $5.400-400=5.000$ \\
\hline & $\begin{array}{l}\text { Mezkûr beş bin aded yüzlük Osmanlı altınının } 1288 \text { senesi Eylül } 12 \text {. } \\
\text { Günü tarihinden itibaren işbu } 1291 \text { senesi Haziran } 12 \text {. Günü tarihine } \\
\text { değin senevî yüzde on ikiden bîl-hesâb } 33 \text { aylık faizi olan }\end{array}$ & 1.650 \\
\hline & Yekûn & $\begin{array}{l}6.650 \text { aded yüzlük } \\
\text { Osmanlı altını }\end{array}$ \\
\hline
\end{tabular}


Ek 4

\section{Mabeyn-i Hümâyûn Kayıtlarına Göre Ressam Chlebowski’ye, Yaptığı Resimleri İçin Ödenen Meblağı Gösteren Liste (BOA, MB, 156/100).}

\begin{tabular}{|c|c|c|}
\hline \multicolumn{2}{|c|}{ Tersim eylediği resimlerden dolayı Ressam Hleboski’ye verilen meblağın miktarı } & \multirow{2}{*}{\begin{tabular}{|l|} 
Guruş \\
40.000 \\
\end{tabular}} \\
\hline \multirow{23}{*}{$\begin{array}{l}\text { Nevres Paşa } \\
\text { Zamanında }\end{array}$} & Kebîr muharebe resmi bahâsı olarak, 12 Haziran 1286 & \\
\hline & Bir aded sagîr muharebe resmi bahâsı olarak, Temmuz 1286 & 10.000 \\
\hline & Bir aded kebîr muharebe resmi bahâsı olarak, Temmuz 1286 & 40.000 \\
\hline & Bir aded sagîr muharebe resmi bahâsı olarak, 24 Ağustos 1286 & 10.000 \\
\hline & Bir aded sagîr muharebe resmi bahâsı olarak, 14 Eylül 1286 & 10.000 \\
\hline & Bir aded sagîr Rum Muharebesi resmi bahâsı olarak, 12 Teşrin-i Evvel 1286 & 10.000 \\
\hline & Bir aded sagîr Orta Nemçe Muharebesi resmi bahâsı olarak, Teşrîn-i Evvel 1286 & 15.000 \\
\hline & Bir aded sagîr muharebe resmi bahâsı olarak, Teşrin-i Sani 1286 & 10.000 \\
\hline & Bir aded orta boy muharebe resmi bahâsı olarak, Kânun-1 Evvel 1286 & 15.000 \\
\hline & Takdim eylediği resimden dolayı ihsan, Kânun-1 Evvel 1286 & 10.000 \\
\hline & Sultan Selim resmi bahâsı olarak, Kânun-1 Evvel 1286 & 10.000 \\
\hline & Saliha Sultan resminden dolayı ihsan, Kânun-1 Evvel 1286 & 5.000 \\
\hline & Sultan Selim resmi bahâsı olarak, 22 Kânun-1 Sâni 1286 & 15.000 \\
\hline & Edirne Muharebesi resmi için ihsan, 14 Şubat 1286 & 15.000 \\
\hline & Nemçe Muharebesi resmi için ihsan, Şubat 1286 & 15.000 \\
\hline & Bir aded Edirne Muharebesi resmi için ihsan, 27 Mart 1287 & 15.000 \\
\hline & \begin{tabular}{|l} 
İhsan, 17 Nisan 1287 \\
\end{tabular} & 10.000 \\
\hline & Paris’ten celb olunan resim ve saire bahâsı olarak, Nisan 1287 & 5.800 \\
\hline & Nemçe Muharebesi resmi için ihsan, 9 Mayıs 1287 & 10.000 \\
\hline & Sultan Selim resmi için ihsan, 21 Mayıs 1287 & 10.000 \\
\hline & \begin{tabular}{|l|l|} 
Sultan Selim-i evvel ve Sultan Selim-i Sâni resimleri için ihsan, 2 Haziran 1287 \\
\end{tabular} & 20.000 \\
\hline & Nemçe Muharebesi resmi için ihsan, 7 Temmuz 1287 & 10.000 \\
\hline & Yekûn & 310.800 \\
\hline \multirow{6}{*}{$\begin{array}{l}\text { Ziver Bey } \\
\text { Zamanında }\end{array}$} & Bir aded Nemçe Muharebesi resmi için ihsan, 26 Ağustos 1287 & 10.000 \\
\hline & Kâğıthane ve Göksu resimleri için ihsan, 18 Eylül 1287 & 10.000 \\
\hline & İhsan, 22 Teşrîn-i Evvel 1287 & 15.000 \\
\hline & İhsan, Teşrîn-i Sâni 1287 & 10.000 \\
\hline & Çend aded çiftlik resim bahâsı olarak, Kânun-1 Evvel 1287 & 17.000 \\
\hline & Yekûn & 62.000 \\
\hline \multirow{5}{*}{\begin{tabular}{|l|} 
Hurşid Bey \\
zamanında \\
\end{tabular}} & Sarı Sultan Selim Hazretlerinin Mohaç Muharebesi ${ }^{76}$ resmi için, 29 Kânun-i Sâni 1287 & 7.000 \\
\hline & Tersim ve takdim eylediği tasvir-i hümâyûn için, 12 Şubat 1287 & 20.000 \\
\hline & Bir aded resim için, Mart 1288 & 10.000 \\
\hline & İhsan, Mayıs 1288 & 15.000 \\
\hline & Yekûn & 52.000 \\
\hline $\begin{array}{l}\text { Mehmed Bey } \\
\text { zamanında }\end{array}$ & 11 Eylül 1288 & 40.000 \\
\hline \multirow{7}{*}{\begin{tabular}{|l|} 
Fuad Bey \\
zamanında \\
\end{tabular}} & İhsan, 14 Teşrîn-i Sâni 1289 & 15.000 \\
\hline & İhsan, 11 Şubat 1289 & 40.000 \\
\hline & Bir aded muharebe resmi bahâsı, 16 Eylül 1286 & 40.000 \\
\hline & Yekûn & 95.000 \\
\hline & YEKÛN GURUȘ & 559.800 \\
\hline & Chlebowski’nin maaş1, gurre-i Teşrîn-i Evvel 1286-Eylül 1288 & 116.333 \\
\hline & GENEL YEKÛN & 676 \\
\hline
\end{tabular}

76 Burada Sarı Sultan Selim'in muharebesi yazılmıştır. Hâlbuki Mohaç Muharebesi Kanuni Sultan Süleyman'ın bizzat katıldı̆̆ meydan muharebesidir. 


\section{Ek 5}

Mabeyn-i Hümâyûn Kayıtlarına Göre Ressam Chlebowski’ye, Yaptığı Resimler İçin Ödenen Meblağı Gösteren Liste

(BOA, MB, 145/132).

\begin{tabular}{|c|c|c|}
\hline Ser-kurena & Ressam Hlebovski'nin tersim eylediği resimler & Guruş \\
\hline \multirow{23}{*}{$\begin{array}{l}\text { Nevres Paşa } \\
\text { Zamanında }\end{array}$} & Kebîr muharebe resmi bahâsı olarak, 12 Haziran 1286 (24 Haziran 1870) & 40.000 \\
\hline & Bir aded sagîr muharebe resmi bahâsı olarak, Temmuz 1286 (13 Temmuz 1870) & 10.000 \\
\hline & Bir aded kebîr muharebe resmi bahâsı olarak, Temmuz 1286 (13 Temmuz 1870) & 40.000 \\
\hline & Bir aded sagîr muharebe resmi bahâsı olarak, 24 Ağustos 1286 (5 Eylül 1870) & 10.000 \\
\hline & Bir aded sagîr muharebe resmi bahâsı olarak, 14 Eylül 1286 (26 Eylül 1870) & 10.000 \\
\hline & Bir aded sagîr Rum Muharebesi resmi bahâsı olarak, 12 Teşrîn-i Evvel 1286 (24 Ekim 1870) & 10.000 \\
\hline & $\begin{array}{l}\text { Bir aded sagîr Orta Nemçe Muharebesi resmi bahâsı olarak, Teşrîn-i Evvel } 1286 \text { (13 Ekim } \\
\text { 1870) }\end{array}$ & 15.000 \\
\hline & Bir aded sagîr muharebe resmi bahâsı olarak, Teşrin-i Sâni 1286 (13 Kasım 1870) & 10.000 \\
\hline & Bir aded orta boy muharebe resmi bahası olarak, Kânun-1 Evvel 1286 (13 Aralık 1870) & 15.000 \\
\hline & Takdim eylediği resimden dolayı ihsan, Kânun-1 Evvel 1286 (13 Aralık 1870) & 10.000 \\
\hline & $\begin{array}{l}\text { Sultan Selim resmi bahâsı olarak, Kânun-1 Evvel } 1286 \text { (13 Aralık 1870) } \\
\text { Sultan Selim resmi bahâsı olarak ihsan, } 22 \text { Kânun-1 Evvel } 1286 \text { (3 Ocak 1871) }\end{array}$ & $\begin{array}{l}10.000 \\
15.000\end{array}$ \\
\hline & Edirne Muharebesi resmi için ihsan, 14 Şubat 1286 (26 Şubat 1871) & 15.000 \\
\hline & Nemçe Muharebesi resmi için ihsan, Şubat 1286 (13 Şubat 1871) & 15.000 \\
\hline & Bir aded Edirne Muharebesi resmi için ihsan, 27 Mart 1286 (8 Nisan 1871) & 15.000 \\
\hline & İhsan, 13 Nisan 1287 (25 Nisan 1871) & 2.000 \\
\hline & İhsan, 17 Nisan 1287 (29 Nisan 1871) & 10.000 \\
\hline & Paris'ten celb olunan resim ve saire bahâsı olarak, Nisan 1287 (13 Nisan 1871) & 5.800 \\
\hline & Nemçe Muharebesi resmi için ihsan, 9 Mayıs 1287 (21 Mayıs 1871) & 10.000 \\
\hline & Sultan Selim resmi için ihsan, 21 Mayıs 1287 (2 Haziran 1871) & 10.000 \\
\hline & $\begin{array}{l}\text { Sultan Selim-i Evvel ve Sultan Selim-i Sâni resimleri için ihsan, } 2 \text { Haziran } 1287 \text { (14 } \\
\text { Haziran 1871) }\end{array}$ & 20.000 \\
\hline & Yekûn & 297.800 \\
\hline & Nemçe Muharebesi resmi için ihsan, 7 Temmuz 1287 (19 Temmuz 1871) & 10.000 \\
\hline & Saliha Sultan resmini tersim için, Kânun-1 Evvel 1286 (13 Aralık 1870) & 5.000 \\
\hline \multirow{10}{*}{$\begin{array}{l}\text { Hurşid Bey } \\
\text { zamanında }\end{array}$} & Bir aded Nemçe Muharebesi resmi için ihsan, 26 Ağustos 1286 (7 Eylül 1870) & 10.000 \\
\hline & Kâğı̀thane ve Göksu resimleri için ihsan, 18 Eylül 1287 (30 Eylül 1871) & 10.000 \\
\hline & İhsan, 22 Teşrîn-i Evvel 1287 (3 Kasım 1871) & 15.000 \\
\hline & İhsan, Teşrin-i Sâni 1287 (13 Kasım 1871) & 10.000 \\
\hline & Çend aded çiftlik resim bahâsı olarak, Kânun-1 Evvel 1287 (13 Aralık 1871) & 17.000 \\
\hline & $\begin{array}{l}\text { Sarı Sultan Selim Hazretlerinin Mohaç Muharebesi }{ }^{77} \text {, resmi için, } 29 \text { Kânun-1 Sâni } 1287 \text { (10 } \\
\text { Şubat 1872) }\end{array}$ & 7.000 \\
\hline & Tersim ve takdim eylediği tasvir-i hümâyûn için, 12 Şubat 1287 (24 Şubat 1872) & 20.000 \\
\hline & Bir aded resim için, Mart 1288 (13 Mart 1872) & 10.000 \\
\hline & İhsan, Mayıs 1288 (13 May1s 1872) & 15.000 \\
\hline & Hurşid Bey zamanında Yekûn & 114.000 \\
\hline \multirow{4}{*}{$\begin{array}{l}\text { Mehmed Bey } \\
\text { Zamaninda }\end{array}$} & 11 Eylül 1288 (23 Eylül 1872) & 40.000 \\
\hline & YEKÛN & 441.800 \\
\hline & $\begin{array}{l}\text { Hlebovski’nin maaş1, gurre-i Receb } 1287 \text { ve } 15 \text { Eylül 1286-28 Receb } 1289 \text { ve } 15 \text { Eylül } \\
1288 \text { (27 Eylül 1870-27 Eylül 1872) }\end{array}$ & 125.000 \\
\hline & YEKÛN GURUŞ & 566.800 \\
\hline
\end{tabular}

77 Bu muharebe, Kanuni Sultan Süleyman'ın bizzat katıldığg meydan muharebesidir. 
Ek 6

Ressam Chlebowski'nin 2 Mayıs 1873 Tarihli Arzuhali

(BOA, I.HR, 268/16125)

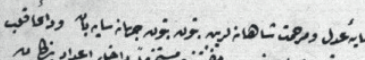

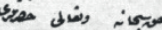

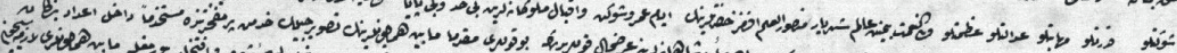

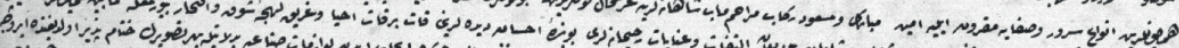

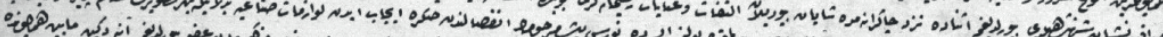

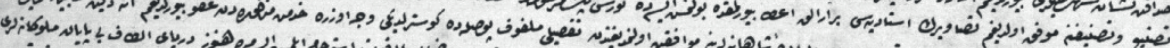

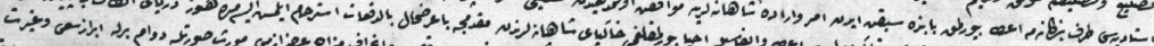

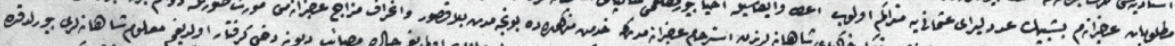

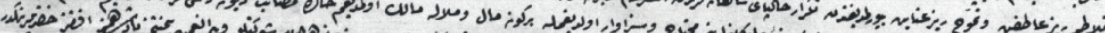

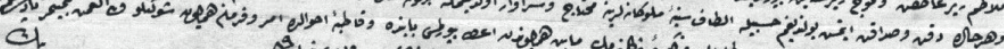

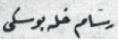

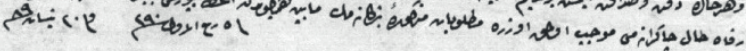

